\title{
Studies on continental Late Triassic tetrapod biochronology. II. The Ischigualastian and a Carnian global correlation
}

\author{
Max Cardoso Langer* \\ Departamento de Biologia, FFCLRP, Universidade de São Paulo (USP), Av. Bandeirantes 3900, 14040-901 Ribeirão Preto, SP, Brazil
}

Received 1 December 2003; accepted 1 December 2004

\begin{abstract}
The Ischigualastian represents a key land vertebrate faunachron for the correlation of Late Triassic terrestrial deposits worldwide, based on the abundant and diverse tetrapod fauna of the Ischigualasto Formation, NW Argentina. The first appearance data of the rhynchosaur Hyperodapedon and the dicynodont Jachaleria define its lower and upper limits, respectively. Fossil taxa that characterize the Ischigualastian include Hyperodapedon, the cynodont Exaeretodon, the aetosaur Aetosauroides, and herrerasaurid dinosaurs. On the basis of faunal similarities, the Ischigualastian can be traced throughout south Pangea to encompass the fossil assemblages of the Hyperodapedon assemblage zone, Santa Maria Formation, south Brazil; the Pebbly Arkose Formation, Zimbabwe; and the Lower Maleri Formation, India. This correlation contradicts tetrapod-based Late Triassic biochronologies that divide the Carnian epoch into two land vertebrate faunachrons, Otischalkian and Adamanian, on the basis of the succession of faunas in some North American continental sequences. However, the extension of these biochronologic units into south Pangea is based mainly on dubious records of index fossils, the taxonomic status of which are not clearly understood. By reassessing the taxonomic status and distribution of tetrapod taxa, this article defines an updated correlation basis for the Late Triassic of Pangea.
\end{abstract}

(C) 2005 Elsevier Ltd. All rights reserved.

Keywords: Biochronology; Carnian; Ischigualastian; Late Triassic; Pangea

\section{The Ischigualastian: Premises and definition}

The term Ischigualastian (='Ischigualastense') was coined by Bonaparte $(1966,1973)$ to designate a reptile age, primarily on the basis of the fossil fauna of the Ischigualasto Formation. This stratigraphic unit crops out in the Ischigualasto provincial park, San Juan and La Rioja provinces, NW Argentina (Fig. 1A), and its thickness averages $600 \mathrm{~m}(650 \mathrm{~m}$ in the type area) though it ranges from 200 to $900 \mathrm{~m}$ in different parts of the IschigualastoIschichuca depocenter of the Bermejo Basin (Milana and Alcober, 1995; Milana, 2002; Stipanicic and Bossi, 2002). On the basis of faunal correlation, previous works have dated the Ischigualasto Formation as Middle Triassic (Romer, 1960, 1962; Reig, 1961, 1963), but a Late Triassic age, first proposed by Bonaparte (1966), has been supported

\footnotetext{
* Tel.: +5516602 3844; fax: +55166331758.

E-mail address: mclanger@ffclrp.usp.br.
}

0895-9811/\$ - see front matter (C) 2005 Elsevier Ltd. All rights reserved. doi:10.1016/j.jsames.2005.04.002 by recent biostratigraphic (Ochev and Shishkin, 1989; Lucas, 1998a) and radiometric (Rogers et al., 1993) studies.

The terrestrial tetrapods of the Ischigualasto Formation (Bonaparte, 1973, 1982, 1997; Marsicano and Arcucci, 2002) compose one of the most diversified Triassic faunas worldwide. Concentrated in the lower two-thirds of the stratigraphic unit (Rogers et al., 1993; Bonaparte, 1997), the fauna includes temnospondyls such as the mastodonsaurid Promastodonsaurus bellmani (Bonaparte, 1963a; Damiani, 2001) and the chigutisaurid Pelorocephalus ischigualastensis (Bonaparte, 1975; Marsicano, 1999; Warren and Marsicano, 2000); the dicynodont Ischigualastia jenseni (Cox, 1965); eucynodonts such as Ecteninion lunensis (Martinez et al., 1996), the chiniquodontid Chiniquodon sanjuanansis (Martinez and Forster, 1996; Abadala and Gianinni, 2002), the travesodontids Exaeretodon frenguellii and Ischignathus sudamericanus (Bonaparte, 1962, 1963b), and a possible juvenile probainognathid (cf. Probainognathus sp.; Bonaparte and Crompton, 1994); the rhynchosaurs Hyperodapedon sanjuanensis (Sill, 1970) and H. mariensis (Contreras, 1981; Langer et al., 2000); various archosaurs such as Trialestes romeri (Bonaparte, 1982; 


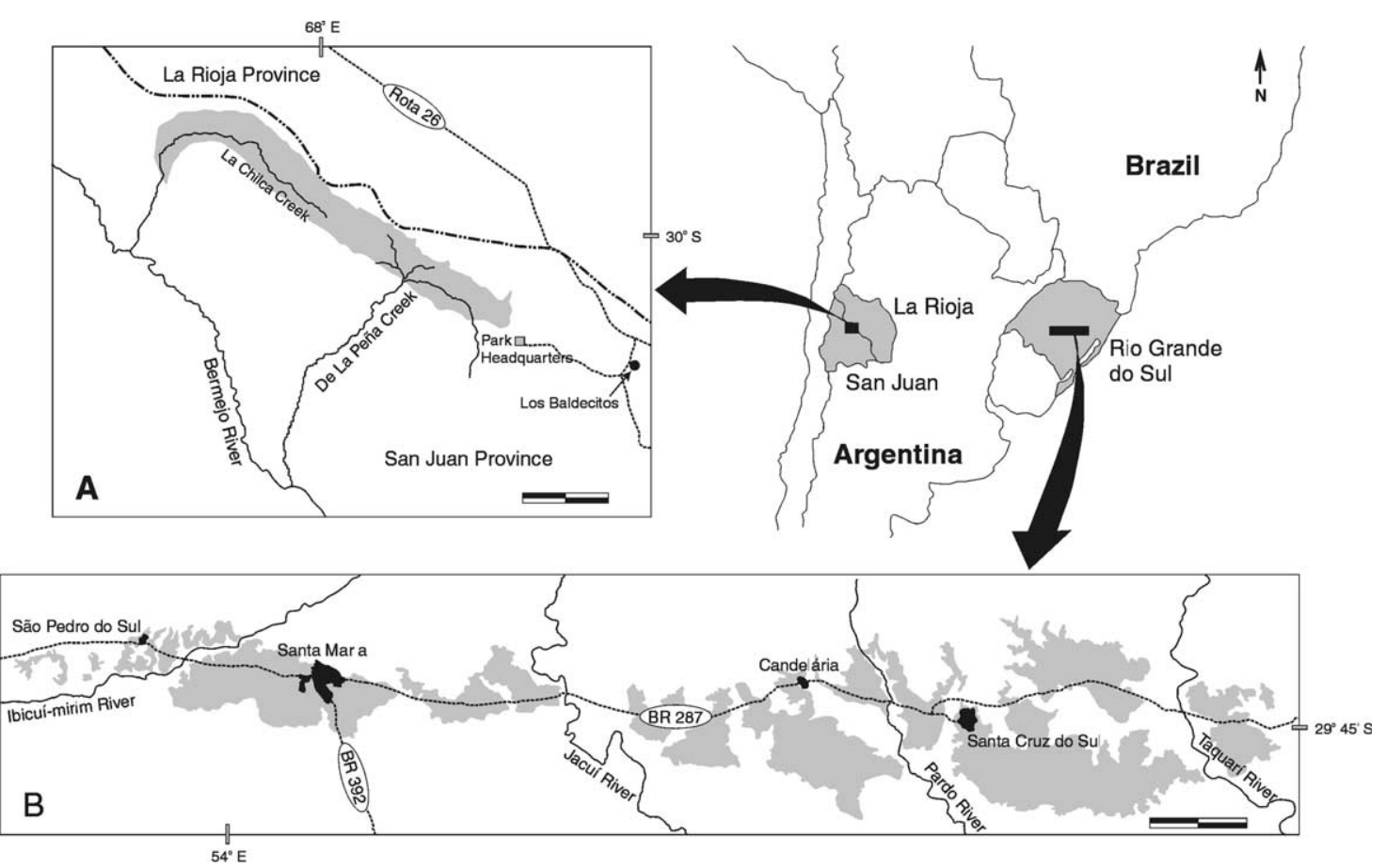

Fig. 1. Location of the tetrapod-bearing strata of Ischigualastian age in South America (black polygons in the base map). (A) Outcrop area (stippled) of the Ischigualasto Formation, Ischigualasto provincial park, San Juan and La Rioja provinces, northeastern Argentina (after Martinez et al., 1996); scale=10 km. (B) Outcrop area (stippled) of the Alemoa Member, Santa Maria Formation, Rio Grande do Sul state, south Brazil (after Faccini, 1989), scale =20 km.

Benton and Clark, 1988), the proterochampsids Proterochampsa barrionuevoi (Sill, 1967) and cf. Chanaresuchus (F. Abdala, pers. comm.), the ornithosuchid Venaticosuchus rusconii (Bonaparte, 1971), the rauisuchian Saurosuchus galilei (Sill, 1974; Alcober, 2000), the aetosaur Aetosauroides scagliai (Casamiquela, 1960; Heckert and Lucas, 2002), the ornithischian dinosaur Pisanosaurus mertii (Bonaparte, 1976), and the saurischian dinosaurs Herrerasaurus ischigualastensis (Sereno and Novas, 1992; Novas, 1993) and Eoraptor lunensis (Sereno et al., 1993).

This article aims to define comprehensively a 'land vertebrate faunachron' (LVF; Lucas, 1998a) characterized by the fossil assemblage of the Ischigualasto Formation, which will inherit the name proposed by Bonaparte (1966). The use of a lithostratigraphically based term to designate biochronologic units has been criticized by Lucas (1998a, p. 349) because it might suggest that it 'refers to the duration of deposition of the formation, not just to the duration of the vertebrate fossil assemblage' (see also Steyer, 2000). The duration of deposition of a lithostratigraphic unit is surely not always equivalent to the duration of the fossil assemblage that typifies it, that is, the type assemblage (sensu Lucas, 1998a). In the case studied herein, the duration of the former is longer because the typical fossils of the Ischigualasto Formation are concentrated in its lower portions.

Lucas (1998a) prefers to name LVFs according to geographic terms related to the areas where their type assemblages were recorded. However, LVFs are not defined on the basis of a type assemblage but merely characterized by it. Accordingly, a strict bond between the name of a LVF and that of its type assemblage would also erroneously suggest that the time interval represented by the LVF is equivalent to the duration of that faunal association. As discussed by Lucas (1998a), the definition of a LVF hangs on nothing but the first appearance data (FAD) of fossil taxa that mark both its beginning and its end. Most commonly, the latter does not occur in fossil assemblages recorded from deposits that directly overly those yielding the type assemblage, and there may be a considerable temporal gap between the last occurrence of the type assemblage of a LVF and the FAD of the fossil taxon that marks its end. Therefore, the time interval represented by a LVF, similar to that equivalent to the deposition of a lithostratigrapic unit, is normally longer than the duration of its typical fossil assemblage.

As independent measures of time, LVFs are not and should not be strictly related to the durations of particular lithologies or faunal associations. They must be clearly defined on the basis of the FAD, and their name can be lithologically, geographically, or paleobiologically related, depending on the adequacy of each case. For the Ischigualasto sequence (Milana, 2002), the concentration of fossil records in the lower beds of both the Ischigualasto (Rogers et al., 1993) and the overlying Los Colorados (Bonaparte, 1997) formations, together with their absence in the upper portions of the former, supports an LVF definition based on the FAD of fossil taxa that occur at the base of the stratigraphic units. Thus, the Ischigualastian better represents the time of deposition of the complete section of 
the Ischigualasto Formation than the occurrence of its typical vertebrate fauna.

Various studies of the tetrapod-based biostratigraphy of the South American Triassic (Bonaparte, 1982; Barberena et al., 1985a,b; Schultz et al., 2001) consider that the Ischigualastian encompasses certain faunas in the Santa Maria and Caturrita Formations in south Brazil (Fig. 1B). Accordingly, that LVF is defined using the FAD of fossil taxa also present in the Late Triassic sequences of south Brazil, in line with the proposal to define the Ischigualastian as a South American LVF, of primary use in the biochronologic correlation of Late Triassic faunas of that continent. In addition, this LVF can be used to correlate fossil assemblages of other parts of Pangea.

The FAD of Hyperodapedon defines the beginning of the Ischigualastian. This rhynchosaur is preferred because of its abundance in the lower portions of the Ischigualasto Formation (Rogers et al., 1993) and because it has never been recorded in older South American deposits, such as the Los Chañares Formation (Bonaparte, 1982) or the Dinodontosaurus assemblage zone of the Santa Maria Formation (Schultz et al., 2001). In addition, Hyperodapedon is abundant in the Alemoa local fauna of the Santa Maria Formation (Barberena et al., 1985b), as well as in Late Triassic faunas worldwide, and thus can be used to trace the Ischigualastian along Triassic strata in and outside South America.

The FAD of Jachaleria defines the end of the Ischigualastian. Unlike Hyperodapedon, this dicynodont has no fossil record outside South America but is preferred because it conspicuously marks the summit of the Ischigualasto Formation deposits at the bottom of the Los Colorados Formation (Bonaparte, 1997; Abdala et al., 2001). Moreover, Jachaleria is present in the Late Triassic sequence of Rio Grande do Sul (Araújo and Gonzaga, 1980; Vega-Dias and Schultz, 2004; Vega-Dias et al., 2004; cf. Lucas, 2003), which enables direct correlation with the Bermejo Basin.

According to Bonaparte (1973), the Ischigualastian fauna is composed predominantly of traversodontids (mainly Exaeretodon) and rhynchosaurs (Hyperodapedon, sensu Langer et al., 2000) and registers the earliest diversification of dinosaurs. The Ischigualastian index fossils defined here meet the general criteria mentioned by Lucas (1998a). More specifically, they also must be (1) present (and preferably common) in south Brazilian correlated faunas, such as the Alemoa local fauna (Barberena et al., 1985a) and faunal association 6 (Schultz, 1995); (2) absent from older assemblages in both Argentina and Brazil, such as the Chanarian (Bonaparte, 1973, 1982; Lucas, 1998a; Schultz et al., 2001) faunas of the Los Chañares Formation and the Dinodontosaurus assemblage zone; and (3) absent from younger assemblages in both Argentina and Brazil, such as assemblages of the Los Colorados (Caselli et al., 2001) and Caturrita (Schultz et al., 2001) Formations.

Exaeretodon is one of the most common (Bonaparte, 1982) members of the Ischigualasto Formation fauna but is unknown from underlying or overlying tetrapod-bearing strata (Bonaparte, 1982; Marsicano and Arcucci, 2002). In addition, it is the tetrapod with the longest stratigraphic range within that stratigraphic unit and occurs throughout almost the entire section (Rogers et al., 1993). Accordingly, on the basis of the fossil record of the Bermejo Basin, Exaeretodon represents an excellent index fossil for the Ischigualastian (see 'Biozona de Exaeretodon', Spalletti et al., 1999; Morel and Artabe, 2002). In his revision of global Triassic biochronology, Lucas (1998a) lists Exaeretodon as a index fossil of the Berdyankian LVF, which is considered coeval to the Chanarian of Bonaparte (1973). The only putative record of Exaeretodon in a Berdyankian (sensu Lucas, 1998a) fossil assemblage-Exaeretodon major in the Dinodontosaurus assemblage zone of the Santa Maria Formation-is based on the isolated maxilla of Traversodon (?) major (Huene, 1935-1942), which was tentatively reassigned by Barberena (1974) (see also Abdala et al., 2002) to Exaeretodon. Therefore, Exaeretodon is not a Berdyankian index fossil.

The distribution of Exaeretodon in the Santa Maria sequence casts some doubt on its validity as an Ischigualastian index fossil. It does not occur in the Ischigualasto-correlated Alemoa local fauna but might appear in the older fauna of Chiniquá (Barberena et al., 1985b). The occurrence of Exaeretodon in the upper beds of the Alemoa Member (faunal association 6 of Schultz, 1995) agrees with the slightly higher abundance of the taxon in the upper portions of the Ischigualasto Formation (Rogers et al., 1993) following the decline of Hyperodapedon. In summary, though Exaeretodon may not strictly define the Ischigualastian, given its possible record in older assemblages in Brazil, it represents an important tool for tracing the Ischigualastian across Pangea, especially during its younger stages, when its abundance contrasts with the scarcity of Hyperodapedon.

The rhynchosaur Hyperodapedon is more abundant than Exaeretodon in the lower portions of the Ischigualasto Formation and virtually absent from the upper half (Rogers et al., 1993). Similarly, in the Santa Maria sequence, it is extremely abundant in the Alemoa local fauna but not in the putatively younger faunal association 6 (Schultz, 1995). Thus, it is considered the Ischigualastian index fossil that better designates the older stages of that LVF. In addition to the occurrence of the taxon, these sequences register the explosive evolution (Romer, 1962) of Hyperodapedon, as in the Alemoa local fauna and the lower Ischigualasto Formation. This peculiar ecologic condition is believed to provide the strongest means to correlate Late Triassic tetrapod faunas within South America and extend that correlation to other parts of Pangea.

Other taxa that cooccur in the Ischigualastian faunas of Argentina and Brazil are Proterochampsa, herrerasaurid dinosaurs, and the aetosaur Aetosauroides. Proterochampsa occurs along most of the Ischigualasto sequence, as well as in faunal association 6, but is unknown outside South America, and has limited biostratigraphical use. Herrerasaurus is typical in the lower portions of the Ischigualasto Formation, 
whereas Staurikosaurus occurs in the Alemoa local fauna. Accordingly, herrerasaurids seem to characterize the early Ischigualastian. Similarly, Aetosauroides occurs in the Alemoa local fauna and the lower parts of the Ischigualasto Formation and might represent an early Ischigualastian index fossil. If the proposed synonymy between Aetosauroides and Stagonolepis (Heckert and Lucas, 2002) and the herrerasaurid affinity of Chindesaurus (Long and Murry, 1995; Langer, 2004) are confirmed, these taxa might provide means to trace the Ischigualastian toward Europe and North America.

\section{Tracing the Ischigualastian throughout south Pangea}

The faunal succession of the Ischigualasto sequence is more properly compared to that of the Late Triassic deposits of the Paraná Basin in south Brazil (Fig. 2). This correlation was the main subject of another contribution to this issue (Langer, 2005) and will not be discussed further herein. This section attempts to trace the Ischigualastian LVF eastward to encompass Late Triassic tetrapod faunas of Africa and India. During the time of deposition of the Ischigualasto Formation, these areas were geographically close to South America (Scotese, 1994; Chatterjee and Scotese, 1999), which made faunal exchange and biostratigraphic correlations feasible. The same is true of Australia and Antarctica, but no significant continental tetrapod faunas of Late Triassic age have been registered on these continents (Schultz, 2004).

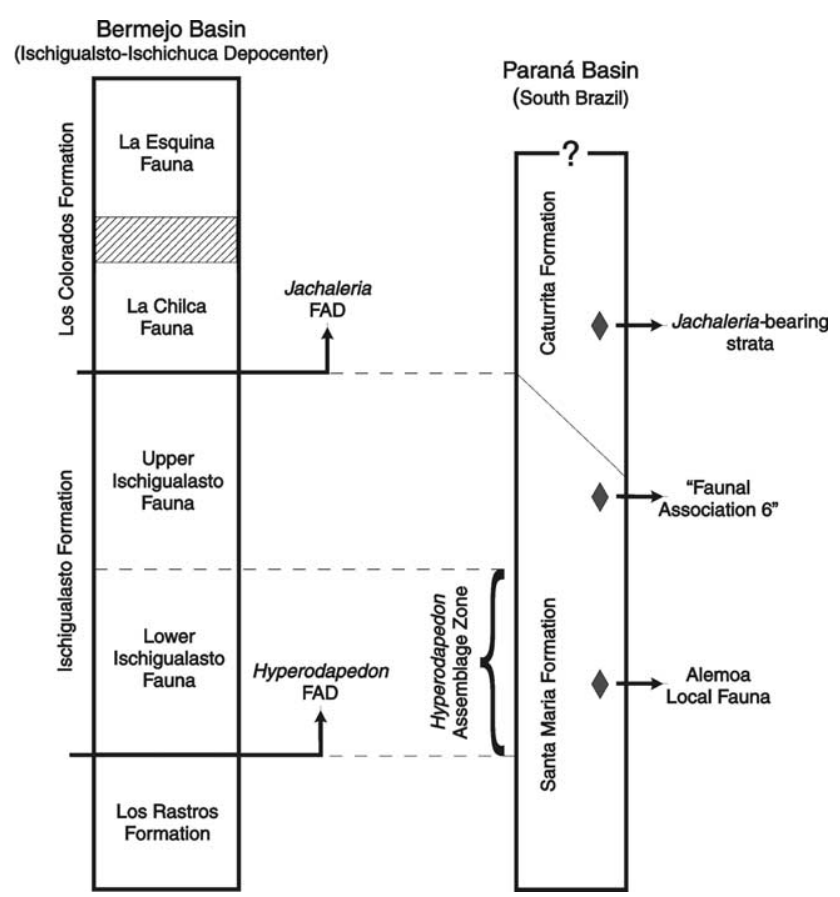

Fig. 2. The Ischigualastian LVF defined for the Late Triassic sequences in the Bermejo Basin (Ischigualasto-Ischichuca depocenter), NE Argentina (Stipanicic, 2002), and Paraná Basin, south Brazil. Alemoa local fauna and faunal association 6 as defined by Barberena et al. (1985b) and Schultz (1995).
Recently, Flynn et al. (1998, 1999, 2000) reported a rich tetrapod fauna from the base of the 'Isalo II beds' (Makay Formation of Razafimbelo, 1987) in the southern part of the Morondava Basin, southwestern Madagascar, including procolophonids, prosauropod dinosaurs, sphenodontians, dicynodonts, traversodontid cynodonts, 'eosuchians,' and rhynchosaurs. Dicynodonts, procolophonids, traversodontids, and rhynchosaurs occur throughout the mid-late Triassic, whereas sphenodontians and prosauropods in the fauna suggest a Late Triassic age (Lucas, 1998a). The oldest records of these taxa (Fraser and Benton, 1989; Gauffre, 1993a; cf. Jalil and Knoll, 2002) come from strata that appear coeval with the Ischigualasto Formation. However, Flynn et al. (1999, 2000) suggest a pre-Ischigualastian age for their Isalo II fauna on the basis of (1) the absence of aetosaurs, (2) the high diversity of traversodontid cynodonts, and (3) the phylogenetic position of the rhynchosaur Isalorhynchus and the traversodontids Dadadon and Menadon.

Aetosaurs are absent from Middle Triassic fossil assemblages (Heckert and Lucas, 2000), including those of pre-Ischigualastian age in South America. However, during the Late Triassic, these archosaurs were not as abundant in south Pangea as in Europe and North America and represent a minor paleofaunal component of the Santa Maria and Ischigualasto Formations (Azevedo et al., 1990; Rogers et al., 1993). Aetosaurs are even less abundant in the Indian Late Triassic (Kutty and Sengupta, 1989) and completely unknown in deposits of that time interval in continental South Africa (cf. Jalil et al., 1995; Lucas, 1998b; Burmeister et al., 2000). Therefore their absence from the Isalo II fauna cannot be considered unequivocal evidence for its pre-Ischigualastian age.

Contrary to Flynn et al. (1999), the diversity of three traversodontids in the Isalo II fauna does not match that of typical pre-Ischigualastian faunas-Massetognathus in the Los Chañares Formation (Abdala and Giannini, 2000) and Pinheiros local fauna, and Traversodon plus Exaeretodon in the Chiniquá local fauna (Barberena et al., 1985b) - better than it does that of Ischigualastian faunas-Exaeretodon plus Ischignathus in the Ischigualasto Formation (Bonaparte, 1997) and Gomphodontosuchus in the Alemoa local fauna (Barberena et al., 1985b). However, three different traversodontids are known in the 'traversodontid biozone' of Abdala et al. (2001), in which they represent the most common faunal component. The dominance, rather than the diversity, of traversodontids might prove more adequate to correlate the Isalo II fauna with pre-Ischigualastian fossil assemblages in South America, such as the Los Chanãres Formation (Bonaparte, 1982; Abdala and Giannini, 2000) and the traversodontid biozone (Abdala et al., 2001).

The phylogentic position of Isalorhynchus is controversial. On the basis of specimens collected from the Makay Formation in the Malio River area, Langer et al. (2000) propose its nesting it in the genus Hyperodapedon, though 
they note some unusual plesiomorphic features that could support a more basal position. Such an intermediate position between typical middle and late Triassic rhynchosaurs was proposed by Whatley et al. (1999) on the basis of specimens of the Isalo II fauna attributed to Isalorhynchus. The source area of the Isalo II fauna seems to lie $30-40 \mathrm{~km}$ west of the Malio River, and more precise data about fossil distribution within the Makay Formation is needed to determine if they belong to the same paleocommunity. In the Santa Maria Formation, faunas of different ages occur in nearby localities with very similar lithology, and biases derived from similar situations must be ruled out in the study of the Malagasy Triassic. For Isalorhynchus, its nesting within Hyperodapedon would strongly suggest an early Ischigualastian age for the Isalo II fauna, whereas its basal position would suggest an older age.

As for the traversodontids, Menadon seems nested within a group composed of Gomphodontosuchus, Exaeretodon, and Scalenodontoides (Flynn et al., 2000; Abdala and Ribeiro, 2003) and more closely related to the latter two taxa. These Exaeretodon-grade traversodontids are typical of Ischigualastian assemblages but also seem to occur in older and younger faunas (Barberena et al., 1985b; Anderson et al., 1998). In contrast, Dadadon appears to represent the sister taxon to Santacruzodon from the traversodontid biozone (Abdala et al., 2001), forming a clade that originates prior to the divergence of the typical mid-Triassic genus Massetognathus (Abdala and Ribeiro, 2003; cf. Flynn et al., 2000). This finding provides another clue for the correlation between the Isalo II fauna and the traversodontid biozone in addition to the dominance of traversodontids, as well as for the pre-Ischigualastian age of the former, as suggested by Flynn et al. (2000).

If the evidence in favor of a pre-Ischigualastian age for the Isalo II fauna is not compelling, that supporting a younger age also is meager. Its prosauropod dinosaur (Flynn et al., 1999) turned out to be a basal archosaur (M. Parrish, pers. comm.), and the sphenodontians (Flynn et al., 1999) apparently represent juvenile rhynchosaurs (R. Whatley, pers. comm.). Accordingly, the correlation of the Isalo II fauna on the basis of continental tetrapods is rather unclear (Fig. 3), though it should be no younger than the Ischigualastian. Palynological studies suggest the correspondence between the Makay Formation and some Carnian strata in western Australia and the Mediterranean (Razafimbelo, 1987), an age also suggested for the base of the Isalo Group according to tectonosedimentary comparisons to the Karroo Basin (Lucas and Heckert, 2002). This evidence is, however, insufficient to support firm statements about the Ischigualastian or pre-Ischigualastian status of the Isalo II fauna. In contrast, Burmeister et al. (2000) report a tetrapod assemblage from the upper portions of the Isalo II beds that yields aetosaurs, phytosaurs, and dinosaurs but not rhynchosaurs or traversodontids. As they note, this assemblage seems to represent a post-Ischigualastian fauna (Fig. 3).

The African Triassic tetrapod assemblage that more properly correlates with the Ischigualastian is the Pebbly Arkose Formation, Cabora Bassa Basin, Zimbabwe (Raath et al., 1992; Oesterlen and Millsteed, 1994). This fauna includes Hyperodapedon (Raath et al., 1992) and a fragmentary femur (Raath, 1996) that seems referable to Saturnalia (Langer et al., 1999). Whereas Hyperodapedon

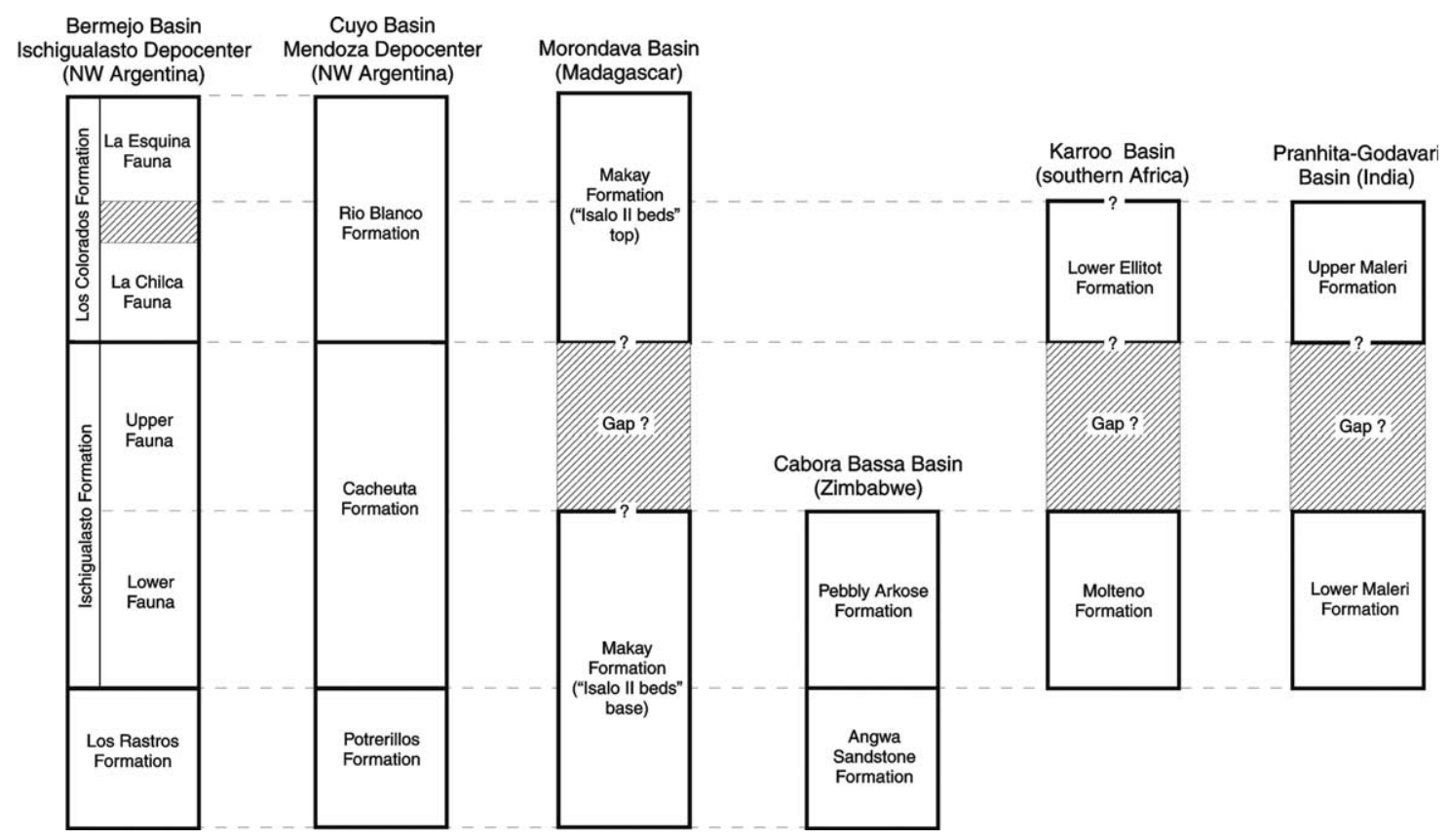

Fig. 3. Correlation chart of the Late Triassic tetrapod faunas of south Pangea depicting the extension of the Ischigualastian LVF into southern Africa and the Indian subcontinent. 
is typical in the lower portions of the Ischigualasto Formation and the Alemoa local fauna, Saturnalia cooccurs with it in the latter. Thus, an early Ischigualastian age can be inferred for the Pebbly Arkose Formation on the basis of its tetrapod fauna (Fig. 3). In addition, the Pebbly Arkose Formation overlies the Angwa sandstone, which seems equivalent to the Rippled Marked Flags of the mid-Zambezi Basin (Raath et al., 1992; Oesterlen and Millsteed, 1994). The paleoflora of Rippled Marked Flags is comparable to that of the Los Rastros and Protrerillos Formations (Anderson and Anderson, 1993), which, respectively, underlie the Ischigualasto Formation and the correlated Cacheuta Formation in the Cuyo Basin (Stipanicic, 2002). Using a similar line of reasoning, Raath (1996) (see also Bond, 1973) correlates the Pebbly Arkose Formation with the Molteno Formation of the Karroo Basin, South Africa.

The rhynchosaur Hyperodapedon is also known from East Africa in an isolated record from south Tanzania (Boonstra, 1953; Chatterjee, 1980a; Langer et al., 2000). The material presumably came from the Tunduru beds (Stockley, 1947), which were considered Jurassic (Hankel, 1987). No other tetrapod remains were reported with this rhynchosaur, and further geological and paleontological research is needed to define the provenance of such material and the correlations of its bearing deposits.

The main Karroo Basin in South Africa seems to lack faunas with typical Ischigualastian characteristics. The Molteno Formation often is correlated with the Ischigualastian beds of South America (Ochev and Shishkin, 1989) but is devoid of tetrapod body fossils. The Lower Elliot Formation traditionally has been considered younger than the Molteno Formation (Olsen and Galton, 1984; Lucas and Hancox, 2001) and to disconformably overlay it (Hancox, 2000). However, Anderson et al. (1998) argue that the Lower Elliot Formation represents the distal facies of the upper four members of the Molteno Formation, an insight into its possible, albeit partial, Ischigualastian age (Gauffre, 1993b).

Tetrapod skeletal remains of the Lower Elliot Formation include (1) a chigutisaurid amphibian of uncertain affinities (Warren and Marsicano, 2000), (2) the possible rauisuchian archosaur Basutodon (Anderson et al., 1998), (3) the traversodontid Scalenodontoides (Hopson, 1984), (4) the basal saurischian dinosaur Aliwalia (Galton and Heerden, 1998), (5) the sauropodomorphs Euskelosaurus and Antetonitrus (Heerden, 1979; Yates and Kitching, 2003), and (6) possible theropod teeth (Ray and Chimsamy, 2002). In addition, trackway records suggest the presence of dicynodonts and turtles (Anderson et al., 1998).

In northwestern Argentina, large rauisuchians are known from the Los Chañares to the Los Colorados Formations (Romer, 1971; Bonaparte, 1981; Alcober, 2000), and Basutodon provides no precise correlation between the Karroo and Bermejo Basins. Similarly, chigutisaurids are known from the Los Rastros and Ischigualasto Formations in the Bermejo Basin (Contreras et al., 1997;
Warren and Marsicano, 2000), as well as from the Cacheuta and Rio Blanco Formations in the Cuyo Basin (Marsicano, 1999; Marsicano and Arcucci, 2002), which are, respectively, coeval to and younger than the Ischigualasto Formation. Together with Aliwalia, which has an uncertain taxonomic position (Langer, 2004), they do not represent good stratigraphic markers.

The absence of Hyperodapedon indicates that the Lower Elliot fauna is younger than early Ischigualastian. More specifically, the lack of any rhynchosaur suggests a postIschigualastian age (Fig. 3). This absence is not believed taphonomic (medium-sized tetrapods are known in the Lower Elliot fauna) or related to insufficient sampling (see Kitching and Raath, 1984), nor does it seem to be a geographic bias, because Hyperodapedon is known from nearby deposits in Zimbabwe and Tanzania. Further evidence of a post-early Ischigualastian age for the Lower Elliot Formation comes from the fossil flora of the underlying Molteno Formation (Anderson and Anderson, 1993), which seems partially coeval with those of the Ischigualastian aged Cacheuta Formation and younger than those of the Los Rastros Formation (Milana and Alcober, 1995) and Rippled Marked Flags overlain by Ischigualastian strata (Fig. 3).

Two main hypotheses pertain to the relative age of the Lower Elliot Formation. On the basis of the occurrence of the traversodontid Scalenodontoides, Gauffre (1993b) proposes its correlation with the Ischigualasto Formation. Various authors (Anderson et al., 1998; Galton and Heerden, 1998; Warren and Damiani, 1999) have followed that premise and assigned a Carnian age to the Lower Elliot Formation. However, Lucas and Hancox (2001) (see also Harris et al., 2002) propose a Norian age for the Lower Elliot Formation on the basis of two lines of argument. First, traversodontids are known in Norian-Raethian faunas in Europe, so the record of Scalenodontoides does not unambiguously indicate a Carnian age. Second, the prosauropod dominance in the Lower Elliot Formation is typical of post-Ischigualastian (post-Carnian) faunas such as those of the German Keuper (Benton, 1983a) and the upper portion of the Los Colorados Formation (Bonaparte, 1982). Although putative prosauropods have been recorded in Ischigualastian faunas (Kutty and Sengupta, 1989; Gauffre, 1993a), they are not as abundant as in the Lower Elliot Formation; this ecological scenario is more consistent with a younger age.

Nonetheless, the record of Scalenodontoides cannot be dismissed as unimportant for the correlation of the Lower Elliot Formation. Its importance is based on its identification not as a traversodontid but as a form closely related to, or even the sister taxon of, Exaeretodon (Hopson, 1985; Flynn et al., 2000; Abdala and Ribeiro, 2003). In this respect, the presence of traversodontids in the NorianRathian of Europe (Hahn et al., 1988; Godefroit and Battail, 1997; Godefroit, 1999) is not relevant, especially because they do not seem closely related to the Late Triassic 
traversodontids of south Pangea. Instead, on the basis of tooth morphology (Abdala and Ribeiro, 2003), they may represent a lineage of their own, separated from the south Pangea stock since the Middle Triassic. In addition, though traversodontids were relatively common until the latest Triassic in Europe, such is not the case in south Pangea (Lucas and Hunt, 1994). Only inconspicuous remains, which cannot be assigned further than Traversodontidae and do not seem to bear any close resemblance to Exaeretodon, have been reported from well-sampled stratigraphic units such as the Los Colorados Formation (Heredia et al., 2004). Thus, given its abundance of basal sauropodomorphs, the Lower Elliot fauna is probably post-Ischigualastian, but the record of Scalenodontoides indicates an older age in relation to the La Esquina fauna of the Los Colorados Formation. This contradictory set of evidence prevents more precise correlations (Fig. 3).

The most important tetrapod-bearing deposits of the Gondwana sequence in the Indian subcontinent occur in the Pranhita-Godavari Valley in the central part of the peninsula (Kutty et al., 1987). According to Kutty and Sengupta (1989), the Late Triassic rocks of that basin include the Maleri and Dharmaram Formations, both of which are divided into lower and upper portions. Among these, the Lower Maleri Formation bears the richer fauna, which usually is considered for intercontinental correlation. Its assemblage of fossil tetrapods includes (1) the temnospondyl Metoposaurus maleriensis (Roy-Chowdhury, 1965; Sengupta, 2002, 2003), (2) the prolacertiform Malerisaurus (Chatterjee, 1980b), (3) the rhynchosaur Hyperodapedon (Chatterjee, 1974), (4) the basal phytosaur Parasuchus (Chatterjee, 1978; Hungerbühler and Chatterjee, 2002), (5) fragmentary aetosaur remains that might be assigned to Longosuchus (Heckert and Lucas, 2000), (6) the basal saurischian Alwalkeria (Chatterjee, 1987), (7) undescribed 'prosauropod' (cf. Massospondylus) remains (Kutty and Sengupta, 1989), (8) undescribed dicynodont remains (Kutty and Sengupta, 1989), and (9) the treversodontid Exaeretodon statisticae (Chatterjee, 1982).

Hyperodapedon is an Ischigualastian index fossil, and Exaeretodon is also typical of that LVF, whereas Alwalkeria resembles Ischigualastian basal saurischians (Langer, 2004), providing the basis to assign an Ischigualastian age to the Lower Maleri fauna. In addition, the abundance of Hyperodapedon in the Lower Maleri $(\sim 60 \%$ of the diversity; Benton, 1983a) is consistent with the explosive evolution of rhynchosaurs recorded in the lower portions of the Ischigualasto Formation and the Alemoa local fauna. Accordingly, an early Ischigualastian age is inferred for the Lower Maleri Formation (Fig. 3). Other members of the Lower Maleri fauna do not allow for a more precise correlation with the South American Late Triassic but are important for cross-correlation of the Ischigualastian with Late Triassic strata in North America and Europe.

The fauna of the Upper Maleri Formation includes (1) two chigutisaurid temnospondyls, Compsocerops and
Kuttycephalus (Sengupta, 1995, 2003; Warren and Marsicano, 2000); (2) two phytosaurs with affinities to Rutiodon (=Angistorhinus) and Leptosuchus (Hungerbühler and Chatterjee, 2002); and (3) fragmentary and undescribed aetosaur, prosauropod, and dicynodont material (Kutty and Sengupta, 1989). Because Hyperodapedon and Exaeretodon apparently disappear in the transition between the Lower and Upper Maleri Formations, the latter is considered younger than the Ischigualasto fauna. In addition, the presence of dicynodonts suggests an older age than the La Esquina fauna of the Los Colorados Formation (Fig. 3).

Chigutisaurid temnospondyls, known in the Upper Maleri and Lower Elliot Formations, experienced their most important radiation in the mid-late Triassic, when they reached South America. Yet, these apparently had separate evolutionary histories in the major geographic areas they occupy-India, Australia, South Africa, and South America (Warren and Marsicano, 2000)-and therefore do not represent good stratigraphic markers. The record of a chigutisaurid in the Late Triassic of North America was mentioned by Chatterjee and Scotese (1999); its further investigation might help stratigraphical correlations.

The Lower Dharmaram Fauna includes fragmentary remains of prosauropods, phytosaurs, and aetosaurs (Kutty and Sengupta, 1989). Of these, the phytosaurs are undiagnostic (Hungerbühler and Chatterjee, 2002), and only the possible record of the aetosaur Paratypotorax has potential biostratigraphic significance (Heckert and Lucas, 2000). Thus, there is not enough evidence to correlate this fauna with the South American Late Triassic.

\section{The north Pangean record}

It is not clear how far the Ischigualastian can be traced into northern Pangea. The most important Ischigualastian index fossil, the rhynchosaur Hyperodapedon, is known in the Lossiemouth Sandstone Formation, northern Scotland (Benton, 1983b); the Middle Wolfville Formation, Nova Scotia (Baird, 1963; Chatterjee, 1980a; Langer et al., 2000); and the Popo Agie Formation, Wyoming (Lucas et al., 2002a). In addition, at least in the Lossiemouth Sandstone Formation, the genus is an important faunal component that represents approximately $25 \%$ of the tetrapod fauna (Benton and Walker, 1985). The aetosaur Stagonolepis, which might represent the sister taxon to Aetosauroides (Parrish, 1994; Heckert et al., 1996; Harris et al., 2003) or even its synonym (Heckert and Lucas, 1999, 2000, 2002), also occurs in the Lossiemouth Sandstone Formation. In addition, the proposed synonymy of some north Pangean aetosaurs (Calyptosuchus, Ebrachosaurus) with Stagonolepis (Heckert and Lucas, 2000) would extend the occurrence of this taxon to various Late Triassic strata of western North America, as well as to the Blasensandstein in southern Germany.

It would be tempting to simply assign an Ischigualastian age to those northern faunas on the basis of the primary 
occurrences of Hyperodapedon and Aetosauroides and the possible synonyms of the latter. However, this case seems more complex. In a series of articles dealing with global Triassic biostratigraphy, Lucas and colleagues (Lucas, 1991, 1998a; Hunt and Lucas, 1991a,b; Lucas and Hunt, 1993a; Lucas and Heckert, 1996) divide the Carnian strata of western North America into two distinct LVFs, the Otischalkian and Adamanian, and extend them into other parts of Pangea. Thus, various putatively coeval Ischigualastian faunas (in both the northern and southern parts of the supercontinent) were assigned to either of these LFVs and given different ages. According to Lucas (1998a) (see also Lucas and Hunt, 1993a), the Otischalkian is the older LVF, and its index fossils include the phytosaurs Paleorhinus and Angistorhinus, the aetosaur Longosuchus, and the temnospondyl Metoposaurus. Adamanian index fossils, in contrast, are the aetosaur Stagonolepis, Rutiodon-grade phytosaurs such as Leptosuchus and Smilosuchus, the dicynodont Ischigualastia, and the rhynchosaur Scaphonyx. On the basis of recent revisions of the latter genus, Lucas and Heckert (2002) have disregarded Scaphonyx as an Adamanian index fossil, and that proposition will not be discussed further.

According to the twofold scheme (Lucas, 1998a), the putatively Ischigualastian faunas of the Popo Agie, Middle Wolfville, and Lower Maleri Formations are Otischalkian, whereas an Adamanian age is given to the Lossiemouth Sandstone and Ischigualasto Formations, as well as to the Hyperodapedon assemblage zone of the Santa Maria Formation. An analysis based on the southern Pangean fossil assemblages, as performed previously, provides no sufficient support for such an ordination of Late Triassic faunas. Accordingly, what evidence from North America suggests this division?

The main basis for the differentiation between Otischalkian and Adamanian LVFs is the supposed recurrence of faunal associations, including the aforementioned index fossils, in various Late Triassic beds of the western United States (Lucas and Hunt, 1993a) and, to some extent, on the North American Atlantic coast (Huber et al., 1993). More important, a superposition of Otischalkian and Adamanian faunas has been reported in the Dockum Group of west Texas (Lucas and Hunt, 1993a). Long and Murry (1995) divided those strata into the so-called 'pre-Tecovas horizon' and Tecovas Formation. The pre-Tecovas horizon corresponds to the Camp Springs Member (formerly Colorado City Member and Iatan Member) of the Dockum Group at Otis Chalk, the fauna of which was used by Lucas and Hunt (1993a) (see also Lucas et al., 1993; Lucas, 1998a) to define the Otischalkian. This fauna includes Otischalkian index fossils such as Longosuchus, Paleorhinus, and Angistorhinus but not Metoposaurus. The latter comes from the putatively coeval fauna of the Elkins Place bone bed, Scurry County (Long and Murry, 1995). The overlying Tecovas Formation yields the Adamanian index fossils Stagonolepis and the Rutiodon-grade phytosaurs
Leptosuchus and Smilosuchus (Lucas, 1998a) but not Ischigualastia. The status of this dicynodont as an Adamanian index fossil was inferred on the basis of the presence of cf. Ischigualastia sp. (Lucas and Hunt, 1993b) in the Los Esteros Member, Santa Rosa Formation, of New Mexico, which yielded other Adamanian index fossils.

This apparently congruent faunal distribution in North America could be used to extend the Otischalkian and Adamanian to other parts of Pangea. Lucas and colleagues proceeded to such an enterprise, but their biochronological scheme presents some problems that deserve further comment. First, there are questions regarding both the taxonomic and the phylogenetic status of various Otischalkian and Adamanian index fossils, as well as their identification in the correlated strata. Second, evidence against a discrete and mutually exclusive ordination of north Pangean Late Triassic faunas as either Otischalkian or Adamanian comes from fossil assemblages that do not conform to the expected composition of those LVFs. These questions are addressed in the following sections in critical analyses of Lucas's Carnian biochronology. This exercise uses the tetrapod fossil record of south Pangea as a template and contrasts with those usually performed by Lucas and colleagues, which mainly have attempted to extend a biochronology based on northern faunal sequences into south Pangea.

\section{Problems with the Otischalkian-Adamanian scheme}

\subsection{Status and appropriateness of index fossils}

Lucas and Heckert (2002) incorporate new evidence from taxonomic revisions of rhynchosaurs into the OtischalkianAdamanian biochronologic scheme but fail to consider studies on some other groups. The distinction between Otischalkian and Adamanian faunas (Lucas, 1998a) has been based on the presence of phytosaurs assigned to either Paleorhinus or Angistorhinus (Otischalkian index fossils) or to the Rutiodon grade (Adamanian index fossils), but the phytosaur taxonomy employed by Lucas and colleagues is not consensual. Hungerbühler (2001) rejects Rutiodon as closely related to Leptosuchus (one of the Rutiodon-grade phytosaurs) and considers it a senior synonym of Angistorhinus (cf. Lucas et al., 2002b). In addition, it is not clear that basal (non-phytosaurid) phytosaurs such as Francosuchus from the Blasensandstein and Parasuchus from the Lower Maleri Formation are synonyms of Paleorhinus (Hungerbühler, 1998; Hungerbühler and Chatterjee, 2002; Wroblewski, 2003), as previously has been proposed and used for biostratigraphic correlation (Hunt and Lucas, 1991a; Lucas, 1998a). This lack of clarity also exists for other nonphytosaurid phytosaurs, such as Francosuchus trauthi from the Opponitzer Schichten, Austria (Hungerbühler, 1998; Wroblewski, 2003), and Paleorhinus magnoculus from the Timesgadiouine Formation, Morocco (Fara and 
Hungerbühler, 2000). Also, the Rutiodon-grade phytosaurs of the Upper Maleri Formation (Lucas, 1998a) were redefined as closely related to both Rutiodon ( = Angistorhinus) and Leptosuchus (Hungerbühler and Chatterjee, 2002).

Because changes in the primary identification of index fossils affect faunal correlation, strata such as the Blasensandstein, Opponitzer Schichten, and the Timesgadiouine and Lower Maleri Formations cannot be directly correlated with the North American Otischalkian on the basis of their 'record' of Paleorhinus. However, the previously mentioned new phytosaur taxonomy maintains the biostratigraphic ordination of the Dockum Group in west Texas with only nomenclatural adjustments (i.e., Rutiodon (=Angistorhinus) and Paleorhinus cooccur in the Camp Springs Member; Leptosuchus and Smilosuchus appear in the Tecovas Formation). A similar situation occurs in the Popo Agie and Timesgadiouine Formations. Records of Angistorhinus (Lucas, 1994; Jalil, 1996) should be referred to Rutiodon, though it does not change their putative correlation with the Otischalkian. On the contrary, the record of Rutiodon (A. Hungerbühler, pers. comm.) in faunas such as those of the Pekin and Cumnock Formations in the Deep River Basin, North Carolina (Huber et al., 1993; Lucas, 1998c), and the Upper Maleri Formation (Hungerbühler and Chatterjee, 2002) does not support the correlation of these strata with the Adamanian of the western United States. Instead, they suggest a correlation with the Camp Springs Member and an Otischalkian age.

Using the much better distribution of aetosaurs, compared with phytosaurs, in south Pangea, Lucas and Heckert (1996) conceived a Late Triassic biochronology based on their fossil record. Lucas (1991) (see also Lucas and Hunt, 1993a) also uses aetosaurs in the definition of western North American LVFs. The distinction between the Otischalkian and the Adamanian was based on the apparently mutually exclusive occurrences of Longosuchus and Stagonolepis, respectively. In the Dockum Group, the stratigraphic distribution of aetosaurs shows Longosuchus in the Camp Springs Member and Stagonolepis (=Calyptosuchus) wellesi in the Tecovas Formation (Long and Murry, 1995; Heckert and Lucas, 2000). According to Heckert and Lucas (2000) (see also Hunt and Lucas, 1990), other records of Longosuchus include the Pekin and Timesgadiouine Formations (Lucas, 1998b,c) and the Salitral Formation, New Mexico (Lucas and Hunt, 1992), as well as possibly the Lower Maleri Formation. Thus, these faunas may be considered coeval to the Camp Springs Member.

Stagonolepis first was described in the Lossiemouth Sandstone Formation (S. robertsoni Agassiz, 1844). The occurrence of the genus in North America was proposed by Murry and Long (1989), who suggest that Calyptosuchus Long and Ballew, 1985, represents its junior synonym. Since then, in general accordance with Murry and Long (1989), various contributions (Long and Murry, 1995; Lucas and Heckert, 1996; Lucas, 1998a; Heckert and Lucas, 2000, 2002; Woody and Parker, 2003) have discussed the distribution of Stagonolepis in North America. These records are based primarily, if not solely (Long and Murry, 1995), on Stagonolepis (=Calyptosuchus) wellesi, though Lucas and Heckert (2001) mention S. robertsoni in the Placerias quarry, Arizona, and the Tecovas Formation, west Texas. Another putative record of Stagonolepis is based on Ebrachosaurus singularis Kuhn, 1936, from the Blasensandstein at Ebrach, Germany (Heckert and Lucas, 2000). In addition, Heckert and Lucas $(1999,2000)$ propose the synonymy of the South American aetosaur Aetosauroides to Stagonolepis (cf. Desojo, 1999), thus extending the record of the latter into the Ischigualasto Formation and Hyperodapedon assemblage zone of the Santa Maria Formation (Lucas and Heckert, 2001; Heckert and Lucas, 2002).

If the inclusiveness of Stagonolepis is accepted as above, the tetrapod faunas of the mentioned stratigraphic units could be correlated with that of the Tecovas Formation and given an Adamanian age. However, some of the taxonomic assignments proposed by Heckert and Lucas (1999, 2000, 2002) are based on the osteoderm morphology of aetosaurs. This procedure seems problematic, especially when dealing with incomplete material (Martz et al., 2003), because it relies on anatomical data provided by limited sources. The phylogenetic reconstructions proposed for the group (Parrish, 1994; Heckert et al., 1996; Heckert and Lucas, 1999) also rely on morphological traits of the dermal armor and are not well supported (Harris et al., 2003). Because taxonomic identifications based on traits related to a single anatomical complex are already problematic, the assignments are even more dubious if the parameters bear a meager phylogenetic signal.

A reanalysis of aetosaur phylogenies (Harris et al., 2003) corroborates the sister-group relationship between Stagonolepis robertsoni and Aetosauroides and sustains claims for their synonymy. In contrast, though the authors regard their results as weakly reliable, they suggest the nesting of 'Stagonolepis wellesi' with more derived aetosaurs rather than with S. robertsoni and Aetosauroides (Harris et al., 2003, Figs. 2a and 9). This suggestion agrees with some morphological traits defined for ' $S$ '. wellesi, such as presacral vertebrae with neural spines higher than central, spikes on the cervical lateral scutes, knob-like dorsal eminences on dorsal paramedial scutes (Heckert and Lucas, 1999; cf. Woody and Parker, 2003), and ventrally keeled paramedial scutes (J. Desojo, pers. comm.). Such characters are not present in either $S$. robertsoni or Aetosauroides but are known in more derived aetosaurs such as Desmatosuchus and Typothorax (Heckert and Lucas, 1999). None of the features listed by Heckert and Lucas (2000) in the diagnosis of Stagonolepis - such as the width-to-length ratio of the dorsal paramedian osteoderms and other traits (see characters 18, 19, 33, 34 and 35 in Heckert and Lucas, 1999)_are unique to the supposedly congeneric group composed of $S$. robertsoni, ' $S$ '. wellesi, and Aetosauroides. Some of these characters might gain apomorphic status depending on the adopted phylogeny, but 
because there is no stable phylogenetic hypothesis for the group (Harris et al., 2003), they cannot be considered apomorphic a priori.

Without unambiguous evidence for a close phylogenetic relationship between Stagonolepis robertsoni and ' $S$ '. wellesi, the synonymy between Stagonolepis and Calyptosuchus is not accepted here as a working hypothesis. Accordingly, in contrast to Lucas (1998a), the occurrence of ' $S$ '. wellesi in the Adamanian faunas of the western United States and of S. robertsoni in the Lossiemouth Sandstone Formation (and probably in the South American Ischigualastian) provide doubtful evidence for the correlation of these stratigraphic-biochronologic units. Nevertheless, Lucas and Heckert (2001) and Heckert and Lucas (2002), respectively, suggest the occurrence of $S$. robertsoni in the Adamanian of the western United States and of ' $S$ '. wellesi in the Ischigualasto Formation. Lucas and Heckert (2001) do not present any justification for this taxonomic assignment, and that mentioned by Heckert and Lucas (2002) is not convincing. The justifications are based on the 'robustness' of the specimens and ornamentation patterns of the dorsal paramedian scutes, which are known in various other aetosaurs and not unique to ' $S$ '. wellesi.

In conclusion, there is only evidence for the occurrence of (1) Stagonolepis robertsoni in the Lossiemouth Sandstone Formation, (2) its sister taxon Aetosauroides in the Ischigualasto Formation and Hyperodapedon assemblage zone of the Santa Maria Formation, and (3) 'S'. wellesi in the Adamanian faunas of the western United States. Of these, only the sister taxon relationship and possibly the synonymy between Stagonolepis robertsoni and Aetosauroides allow a biostratigraphic correlation between the Lossiemouth Sandstone Formation and the South American Ischigualastian.

Lucas and Hunt (1993b) describe various dicynodont postcranial elements from a putatively Adamanian-age deposit: the upper part of the Los Esteros Member, Santa Rosa Formation, New Mexico. These remains have been assigned to cf. Ischigualastia sp. mainly on the basis of the anatomy of an isolated femur, which does not conform to that of Placerias, the most common dicynodont from the North American Late Triassic. In the biostratigraphic scheme of Lucas and colleagues, this record suggests a correlation between the Los Esteros Member and the Ischigualasto Formation and, consequently, between the Adamanian and the South American Ischigualastian. Prior to the suggested synonymy of Aetosauroides with Stagonolepis, this was the major basis for that correlation (Lucas, 1998a). Although they accept that the femur is dissimilar to that of Placerias, Long and Murry (1995) contest even its tentative assignment to Ischigualastia. As they note, the bone could belong to other 'stahleckeriid' dicynodonts such as Dinodontosaurus or Stahleckeria, both of which are known from Mid-Triassic deposits in South America (Bonaparte, 1982; Schultz et al., 2001). This more cautious taxonomic approach is followed herein; the femur of the
Los Esteros Member provides no strong basis for correlating the South American Ischigualastian with the Adamanian. In addition, the proper biochronological assignment of the fauna of the Los Esteros Member is not fully understood, and its Adamanian age is uncertain.

In a review of the European metoposaur temnospondyls, Sulej (2002) challenges some conceptions of the taxonomy proposed by Hunt (1993) for the group, which has been frequently used for biostratigraphic purposes (Lucas and Hunt, 1993a; Lucas, 1998a). On the basis of the anatomy of the lachrymal bone, Sulej (2002) questions the assignment of the North American Buettneria bakeri Case, 1931, to Metoposaurus (Hunt, 1993) and considers M. diagnosticus the single valid species of the genus. Accordingly, this challenges the correlation between the European faunas that contain M. dignosticus (for a review, see Sulej, 2002) and those of North America that bear Buettneria bakeri, such as the Elkins Place bone bed (Hunt, 1993; Long and Murry, 1995) and the Middle Wolfville Formation of the Fundy Basin (Baird, 1986; Milner, 1994). The record of Metoposaurus is therefore restricted to the German Middle Keuper and the Krasiejów locality in Poland (Sulej, 2002) and is not useful for intercontinental correlation.

The assignment of the Indian metoposaur, 'Metoposaurus' maleriensis Roy-Chowdhury, 1965, to Buettneria perfecta, as proposed by Hunt (1993), also was questioned by Sulej (2002). In the southwestern United States, Buettneria perfecta seems to occur throughout the Otischalkian-Adamanian time interval (Long and Murry, 1995; Lucas, 1993, 1998a). B. bakeri, in contrast, apparently is confined to Otischalkian faunas, in support of their correlation with the Middle Wolfville Formation. According to Long and Murry (1995), the distribution of Apachesaurus gregori does not overlap that of $B$. bakeri but is restricted to younger faunas. However, Lucas et al. (1993) mention the occurrence of Apachesaurus isolated intercentra in the Camp Springs Member at Otis Chalk. The distribution of this taxon is significant because as it might represent the sister taxon to Arganasaurus lyazidi from the top of the Irohalene Member, Argana Basin, Morocco (Zanno et al., 2002).

Heckert et al. (2002) attribute tooth-bearing fragments from the Blue Mesa Member, Petrified Forest Formation, Blue Hills area, Arizona, to the carnivorous archosaur Saurosuchus. Lucas (1993) considers that stratigraphic unit equivalent to the deposits that yield the Adamanian-type assemblage in the Petrified Forest National Park. Saurosuchus previously was recognized only in the Ischigualasto Formation. (Alcober, 2000), and Heckert et al. (2002) believe the new find corroborates the Adamanian age of that stratigraphic unit. These authors rely on the presence of dermal sculpture on the lateral surface of the maxilla to assign the Blue Hills archosaur to Saurosuchus, but the pattern described for Saurosuchus consists of an irregular network of grooves (Sill, 1974) around the antorbital fenestra (Alcober, 2000), namely, the antorbital fossa sensu Witmer (1997), which is not congruent with the 
subparallel elongate grooves and ridges not concentrated near the antorbital fossa (Heckert et al. 2002, Fig. 3b) of the Blue Hills archosaur. Thus, the presence of Saurosuchus in North America and its consequent correlations are doubtful.

\subsection{Rogue occurrences and the correlation of north Pangea faunas}

Otischalkian and Adamanian index fossils often are registered in the same fauna, as in the Placerias quarry and Blasensandstein (Heckert and Lucas, 2000). These joint occurrences, however, are of minor significance in the twofold scheme of Carnian biostratigraphy proposed by Lucas (1998a) (cf. Heckert and Lucas, 1997). However, they provide crucial data for understanding the faunal succession within that time interval. There are at least two important western U.S. Late Triassic faunal assemblages in which Otischalkian and Adamanian index fossils are reported together: the Los Esteros Member, Santa Rosa Formation, eastern new Mexico, and the Bluewater Creek Formation, Chinle Group, at Placerias and Downs' quarries, Arizona.

In the Placerias and Downs' quarries (Kaye and Padian, 1994; Long and Murry, 1995; Lucas et al., 1997), the Otischalkian index fossil Paleorhinus occurs with the Adamanian index fossils Leptosuchus and 'Stagonolepis' wellesi, and the last two forms occur together with Rutiodon (=Angistorhinus, an Otischalkian index fossil) in the Los Esteros Member (Hunt and Lucas, 1993; Lucas, 1998a). This pattern matches a similar occurrence in the Pranhita-Godavari Basin, where forms with affinities to Rutiodon and Leptosuchus occur together in the Upper Maleri Formation (Hungerbühler and Chatterjee, 2002). Heckert and Lucas (2000) consider the fauna of the Placerias and Downs' quarries to be at the onset of the Adamanian (see also Lucas et al., 1997). Alternatively, this fauna, like that of the Los Esteros Member, may be considered intermediate between the typical Otischalkian and Adamanian faunas, which would mach the lower stratigraphic position of its bearing rocks (Bluewater Creek Formation) in relation to the typical Adamanian faunas in the Petrified Forest Formation (Heckert and Lucas, 1997, 2003).

Fig. 4 depicts a biochronologic chart for north Pangea faunas, in which intermediate faunas such as those of the Placerias and Downs' quarries and Los Esteros Member are incorporated into the Otischalkian-Adamanian scheme of Lucas and colleagues, as is represented by the faunal succession of the Dockum Group (Camp Springs Member and Tecovas Formation). Among the Adamanian index fossils (Lucas, 1998a), only the phytosaur Smilosuchus does not occur with Otischalkian taxa in intermediate faunas. Accordingly, its FAD is believed to be younger than those of Leptosuchus and 'Stagonolepis' wellesi and allows a more detailed biostratigraphic correlation. Whereas Lucas and coworkers. divided the discussed time interval into two faunal stages, the beginning of which were marked by the Paleorhinus and Leptosuchus FADs, a threefold subdivision, in which the FAD of Smilosuchus is incorporated to define the beginning of a younger stage, is advocated here.

The oldest faunal stage depicted in Fig. 4 is defined by the FADs of Paleorhinus (beginning) and Leptosuchus

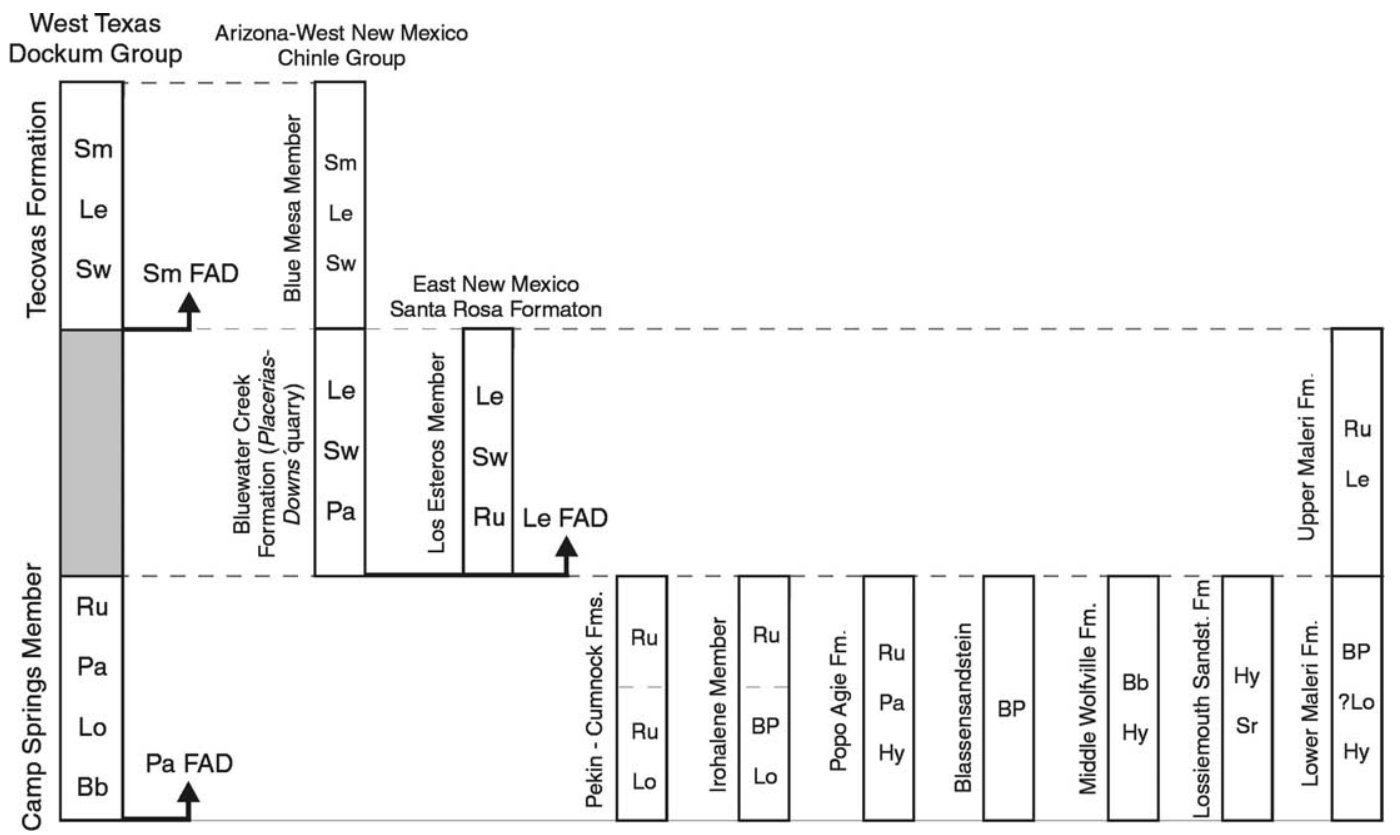

Fig. 4. Correlation chart of Late Triassic tetrapod faunas of north Pangea based on comparisons with the faunas of the Dockum Group in west Texas and the 'intermediate' faunas of the Placerias and Downs' quarries and Los Esteros Member. Abbreviations: Ae, Aetosauroides; Bb, Buettneria bakeri; BP, nonphytosaurid phytosaurs; Hy, Hyperodapedon; Le, Leptosuchus; Lo, Longosuchus; Pa, Paleorhinus; Ru, Rutiodon; Sm, Smilosuchus; Sr, Stagonolepis robertsoni; and Sw, 'Stagonolepis' wellesi. 
(end). Accordingly, the occurrence of Paleorhinus and/or Rutiodon in the absence of Leptosuchus identifies faunas that belong to that time interval, as is the case of the Popo Agie Formation (Lucas, 1994); New Oxford Formation, Pennsylvania (A. Hungerbühler, pers. comm.; see also Doyle and Sues, 1995); the fauna of Krasiejów, Poland (Dzik, 2001); the top of the Irohalene Member, Timesgadiouine Formation; and the Pekin and Cumnock Formations, North Carolina (Lucas, 1998b,c). In addition, because the aetosaur Longosuchus seems to occur uniquely within this faunal stage, its presence in the Pekin Formation and at the base of the Irohalene Member (Lucas, 1998b,c) suggests the same correlation. Using the phylogenetic position of Paleorhinus, it is also possible to extend this correlation to assemblages that bear an abundant phytosaur fauna or non-phytosaurid forms in the absence of Leptosuchus, as is the case of the Blasensandstein (Hungerbühler, 1998), the Lower Maleri Formation (Hungerbühler and Chatterjee, 2002), and the base of the Irohalene Member (Fara and Hungerbühler, 2000). Finally, the presence of Buettneria bakeri in the Middle Wolfville Formation suggests direct correlation with the 'pre-Tecovas' horizon (Long and Murry, 1995) in west Texas and a basal position within the threefold subdivision.

The intermediate faunal stage is defined by the FADs of Leptosuchus (beginning) and Smilosuchus (end), that is, by the faunas that bear Leptosuchus, together or not with Otischalkian index fossils (Rutiodon and Paleorhinus) but not Smilosuchus. As was previously discussed, the faunas of the Placerias and Downs' quarries, Los Esteros Member, and Upper Maleri Formation belong to that category (Fig. 4), whereas faunas in which Leptosuchus cooccurs with Smilosuchus, usually in the absence of Paleorhinus or Rutiodon, belong to the younger faunal stage. The faunas of the Blue Mesa Member, Petrified Forest Formation (Adamanian-type assemblage, see Lucas, 1998a), and Tecovas Formation fit this faunal stage. However, increasing evidence indicates that non-phytosaurid phytosaurs occur in younger strata in the western US Late Triassic, as is the case of Promystriosuchus from the Tecovas Formation and possibly records of Paleorhinus in both the Tecovas Formation (A. Hungerbühler, pers. comm.) and the lower Cooper Canyon Formation (Hunt and Lucas, 1991a). These records suggest a broader chronological distribution for the basal phytosaurs than previously proposed, at least in the western United States.

The Lossiemouth Sandstone Formation (Benton and Walker, 1985) was previously correlated with western North American strata on the basis of the occurrence of Stagonolepis (Lucas, 1998a; Heckert and Lucas, 2002). However, uncertainties regarding the presence of that genus in North America, as noted previously, still exist. The rhynchosaur Hyperodapedon, a dominant component of the fossil assemblage of the Lossiemouth Sandstone Formation, also occurs in various North American faunas. Rhynchosaurs are not abundant in the Late Triassic of North
America, but Hyperodapedon was recorded in both the Middle Wolfville and the Popo Agie Formations (Langer et al., 2000; Lucas and Heckert, 2002; Lucas et al., 2002a). Furthermore, fragmentary rhynchosaur remains have been reported in both the Camp Springs Member and the Tecovas Formation within the Dockum Group (Long and Murry, 1995). The rhynchosaurs of the Camp Springs Member (Otischalkia elderae Hunt and Lucas, 1991b, nomen dubium) are more complete but cannot be specified to the genus level, though they probably represent a hyperodapedontine (sensu Langer and Schultz, 2000). The putative rhynchosaur remains from the Tecovas Formation seem too fragmentary for a precise taxonomic assignment (Long and Murry, 1995), so all presently reliable records of Hyperodapedon in North America come from faunas placed in the lower subdivision of the threefold biostratigraphical scheme of Fig. 4. Therefore, on the basis of the occurrence of this rhynchosaur, the fauna of the Lossiemouth Sandstone Formation and the Lower Maleri Formation are proposed to correlate with that faunal stage.

\section{Extending the Ischigualastian into northern Pangea}

The fossil taxa that define the Ischigualastian, according to their FADs, are either absent (Jachaleria) or relatively rare (Hyperodapedon) in the Late Triassic faunas of north Pangea. To better correlate those fauna, the Ischigualastian must be redefined on the basis of the FADs of faunal components that are widespread and abundant in the northern part of the supercontinent. In south Pangea, the Ischigualastian marks the first occurrence of aetosaurs, phytosaurs, and metoposaurs, all of which are common components of northern Pangea fauna. Whereas aetosaurs are well represented in the South American Ischigualastian (Heckert and Lucas, 2002) and poorly known in the Maleri Formation (Kutty and Sengupta, 1989), the other two tetrapod groups have their southern Pangea fossil record concentrated in that Indian sequence.

The Maleri Formation traditionally was considered to include a mixture of typical south and north Pangean fauna components, namely, the 'Rhynchosaur/Diamodontid' versus the 'Metoposaur/Phytosaur' empires of Benton (1983a); (see also Cooper, 1982; Olsen and Galton, 1984; Chatterjee and Hotton, 1986; Ochev and Shishkin, 1989; Shubin and Sues, 1991). It therefore represents a good template for Late Triassic south-north correlations. In addition, the Maleri Formation contains two distinct, superimposed fossil assemblages, which facilitates biostratigraphic comparisons.

As was previously discussed, the fauna of the Lower Maleri Formation is of early Ischigualastian age, and that of the Upper Maleri Formation is probably post-Ischigualastian (Fig. 3). Accordingly, the beginning and end of the Ischigualastian are redefined here on the basis of the FADs of faunal components of, respectively, the Lower and 


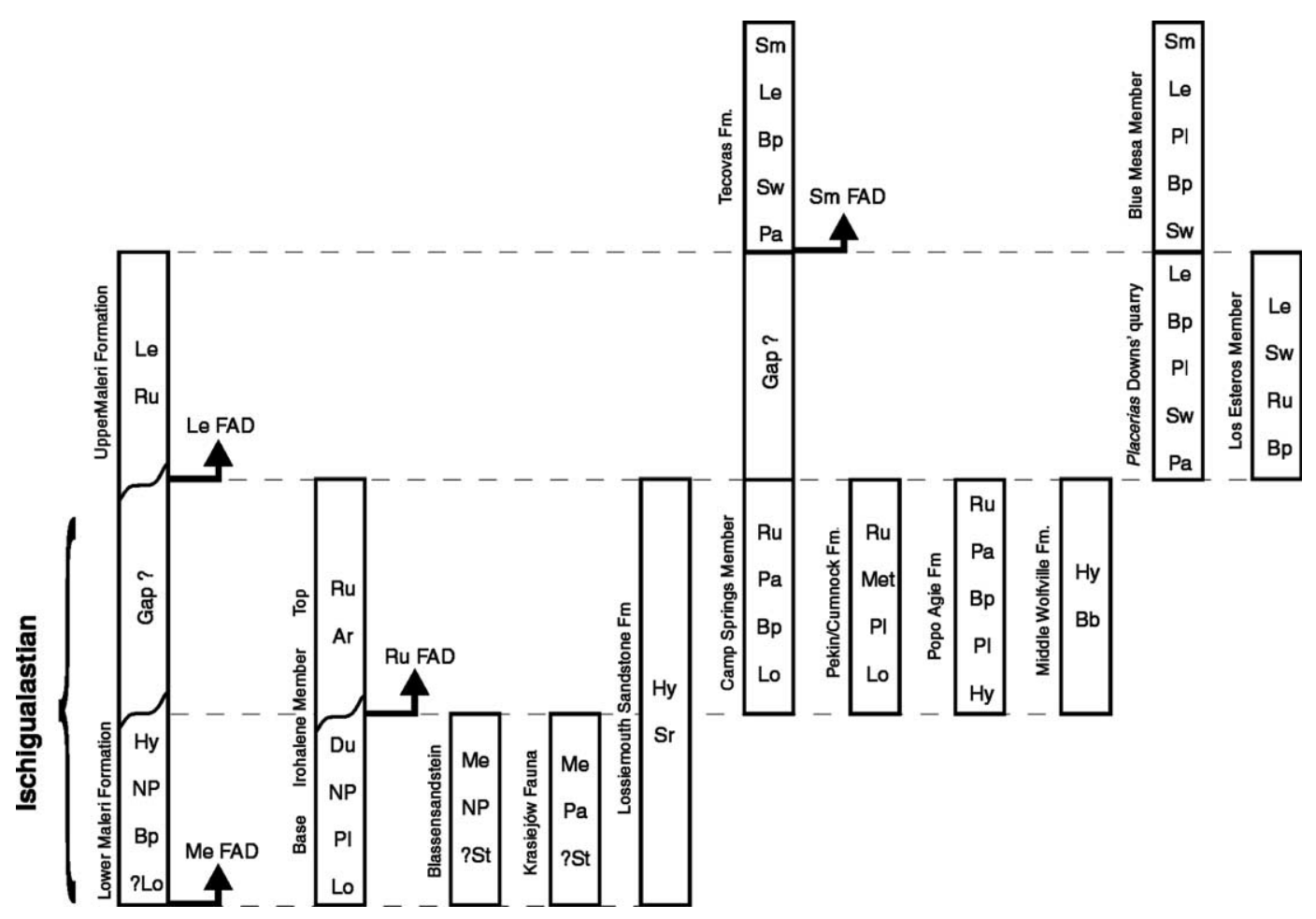

Fig. 5. Correlation chart of Late Triassic tetrapod faunas of north Pangea based on comparisons with the faunal succession in the Maleri sequence, PranhitaGodavary Basin, India. Abbreviations: Ar, Arganasaurus; Bb, Buettneria bakeri; Bp, Buettneria perfecta; Du, Dutuitosaurus; Hy, Hyperodapedon; Le, Leptosuchus; Lo, Longosuchus; Me, Metoposaurus; Met, metoposaurs; NP, non-phytosaurid phytosaurs; Pa, Paleorhinus; Pl, Placerias; Ru, Rutiodon; Sm, Smilosuchus; Sr, Stagonolepis robertsoni; St, Stagonolepis; and Sw, 'Stagonolepis' wellesi.

Upper Maleri Formations that also are common in north Pangea. That is, the FAD of metoposaurs marks its beginning (subsidiary FADs that putatively define the same timeline are those of aetosaurs, phytosaurs, and hyperodapedontine rhynchosaurs), and the FAD of Leptosuchus marks its end (Fig. 5). Because this LVF is based on the FADs of different taxa, it does not necessarily represent the same time interval as the original Ischigualastian.

As for the phytosaurs known in the Upper Maleri Formation, Leptosuchus (rather than Rutiodon) defines the end of the Ischigualastian because its FAD marks the beginning of the Adamanian (Lucas, 1998a) and as given by the North American distribution (Fig. 4), defines a younger timeline than that of Rutiodon. A later FAD is preferable to represent the end of the redefined Ischigualastian because the Lower Maleri Formation does not seem to include the Hyperodapedon-impoverished faunal stage that characterizes the upper part of the LVF in South America. Even so, the FAD of Rutiodon represents the beginning of an earlier faunal stage within the north Pangean Ischigualastian (Fig. 5).

The northern Pangean faunas that correlate more directly with a biochronological scheme based on the Maleri sequence are those of the Timesgadiouine Formation in the Argana Basin, Morocco (Jalil, 1996, 1999). The base of the Irohalene Member includes, among others, the metoposaur Dutuitosaurus ouazzoui (Hunt, 1993), the aetosaur Longosuchus (Lucas, 1998b), dicynodonts that may represent the North
American genus Placerias (Lucas and Wild, 1995), and the non-phytosaurid phytosaur 'Paleorhinus' magnoculus (Hunt and Lucas, 1991a; Fara and Hungerbühler, 2000). The top of the unit contains the metoposaur Arganasaurus lyazidi (Hunt, 1993) and the phytosaur Angistorhinus talainti (= Rutiodon, sensu Hungerbühler, 2001).

The base of the Irohalene Member therefore may be correlated with the Lower Maleri Formation, both of which possess non-phytosaurid phytosaurs but not Rutiodon. In contrast, the top of the Irohalene Member contains Rutiodon but not Leptosuchus and is placed above and below their respective FADs. As a consequence, the entire Irohalene Member fits into the Ischigualastian of north Pangea. Its base represents a pre-Rutiodon FAD stage of that LVF, whereas its top belongs to a post-Rutiodon FAD faunal stage (Fig. 5). In the Deep River Basin, North Carolina, Rutiodon cooccurs with Longosuchus, Placerias, and metoposaurs in the Pekin Formation (A. Hungerbühler, pers. comm.) and appears in the overlying Cumnock Formation (Lucas, 1998c). Because Leptosuchus is absent from both faunas, they can be assigned to a post-Rutiodon FAD stage in the Ischigualastian of north Pangea (Fig. 5).

In the Middle Keuper, the fauna of the Blasensandstein include Metoposaurus diagnosticus (Sulej, 2002; cf. Hunt, 1993; Schoch and Milner, 2000), the non-phytosaurid phytosaur Francosuchus (Kuhn, 1932, 1936; Hungerbühler, 1998), and the aetosaur Ebrachosaurus, which might 
correspond to Stagonolepis (Benton and Walker, 1985; Heckert and Lucas, 2000). This suggests a pre-Rutiodon FAD stage in the north Pangea Ischigualastian (Fig. 5), as in the case of the Krasiejów fauna, which yielded Metoposaurus diagnosticus (Sulej, 2002), the dinosauromorph Silesaurus (Dzik, 2003), Paleorhinus, and possible records of Stagonolepis (Dzik, 2001). Accordingly, the records from the Argana Basin, German Keuper, and Krasiejów fauna suggest that Placerias, Longosuchus, non-phytosaurid phytosaurs (including Paleorhinus), and metoposaurs (including Metoposaurus and Dutuitosaurus) occur since the base of the Ischigualastian in the Late Triassic of north Pangea.

Other putative Ischigualastian faunas of north Pangea include those of the Camp Springs Member and the Popo Agie Formation. Both faunas include Rutiodon but not Leptosuchus, which indicates a post-Rutiodon FAD Ischigualastian age (Fig. 5). They also contain Paleorhinus and Buettneria perfecta (Hunt, 1993); Hyperodapedon occurs in the Popo Agie Formation (Lucas et al., 2002a) and Longosuchus in the Camp Springs Member (Lucas et al., 1993). These data, plus those of the Deep River Basin, indicate the extension of the stratigraphic record of Longosuchus, Paleorhinus, Placerias, Hyperodapedon, and Buettneria perfecta into post-Rutiodon FAD faunal stages and throughout the Ischigualastian of north Pangea. The metoposaur Apachesaurus seems to appear for the first time in this faunal interval (Lucas et al., 1993), which suggests a correlation with the top of the Irohalene Member, Argana Basin, which contains its possible sister taxon Arganasaurus (Zanno et al., 2002).

The faunas of both the Middle Wolfville Formation, Nova Scotia, and the Lossiemouth Sandstone Formation, northern Scotland, include Hyperodapedon; that of the Middle Wolfville Formation also contains Buettneria bakeri (Sulej, 2002), and that of the Lossiemouth Sandstone Formation bears Stagonolepis robertsoni (Walker, 1961). The occurrence of Buettneria bakeri in the Elkins Place bone bed, putatively coeval to the Camp Springs Member, suggests a post-Rutiodon FAD Ischigualastian age for the Middle Wolfville Formation. As for the Lossiemouth Sandstone Formation, without uncontroversial records of $S$. robertsoni in other parts of north Pangea, the Hyperodapedon merely suggests an undifferentiated Ischigualastian age (Fig. 5).

The ordination among the post-Leptosuchus FAD vertebrate faunas of north Pangea was discussed in the previous section. These faunas belong to post-Ischigualastian stages and are younger than those of both the Ischigualasto and Lower Maleri Formations. Some are considered coeval to that of the Upper Maleri Formation and assigned an intermediary age in the updated faunal correlation of the western United States (Fig. 4), including the faunas of the Placerias and Downs' quarries and the Los Esteros Member (Fig. 5), which contains Buettneria perfecta, Apachesaurus, Placerias, Paleorhinus, and
Rutiodon (Long and Murry, 1995; Lucas et al., 1997; Lucas, 1998a). Thus, such forms appear to have survived the end of the Ischigualastian in north Pangea. The aetosaur 'Stagonolepis' wellesi appears for the first time in this faunal interval. The faunas of the Tecovas Formation and Blue Mesa Member, in contrast, belong to a higher faunal stage compared with those of the Upper Maleri Formation and the Placerias and Downs' quarries (Fig. 5). The occurrence of Buettneria perfecta, Placerias, and possibly Paleorhinus in these faunas indicates the wide range of the taxa in the Late Triassic of north Pangea. Other discussed faunal components that survive from previous stages are Apachesaurus and 'Stagonolepis' wellesi.

\section{Ischigualastian time correlation}

A precise age assignment for Late Triassic tetrapod faunas is a notorious problem because of the difficulty of correlating most tetrapod-bearing continental rocks with well-dated marine sequences (Lucas and Heckert, 2000) or fitting them into the standard palynological zonation of that time interval (Olsen and Sues, 1986; Benton, 1994). Late Triassic palynoflorules of north and south Pangea are reputed to be radically different (Olsen and Sues, 1986), and their temporal acuity seems poorer than necessary (Benton, 1994). The record of tetrapods therefore may be useful for correlating Late Triassic continental deposits (Cooper, 1982; Ochev and Shishkin, 1989; Anderson and Anderson, 1993; Lucas, 1998a; Schultz, 2004), despite the usually coarse biochronological information they provide. This section deals with the slight evidence that enables a direct correlation of the previously discussed tetrapod faunas with the Late Triassic 'standard time scale,' as well as with the established ammonoid and palynological zonations of that time interval.

The radioisotopic dating of the 'Herr Toba' bentonite at the base of the Ischigualasto Formation (Rogers et al., 1993) represents the most important contribution to the time correlation of the Ischigualastian LVF. It provides a ${ }^{40} \mathrm{Ar} /{ }^{39} \mathrm{Ar}$ age of $227.8 \pm 0.3 \mathrm{Ma}$, which corresponds to the early Carnian (Ross et al., 1994; Gradstein and Ogg, 1996; Remane et al., 2000; cf. Harland et al., 1990; Kent and Olsen, 1999). The 'Herr Toba' bentonite is interbedded with Hyperodapedon-bearing strata of the Ischigualasto Formation (Rogers et al., 1993). Considering the sedimentation rate in similar rift basins (Rogers et al., 1993; Abdala et al., 2001), the entire Ischigualasto Formation is considered early-mid Carnian, an age assumed for the Ischigualastian LVF. Thus, the fossil-bearing lower sections of that unit, especially the Hyperodapedon-rich layers (Bonaparte, 1982, 1997; Rogers et al., 1993), are of early Carnian age.

The non-tetrapod-based correlation of putative Ischigualastian strata in southern Africa does not contradict the early-mid Carnian age assigned to that LVF. The palynostratigraphy of the Pebbly Arkose and Makay Formations 
suggests an undifferentiated Carnian age (Bond, 1973; Razafimbelo, 1987). Similarly, an undivided or early Carnian age (Anderson, 1981; Anderson and Anderson, 1983, 1993; Anderson et al., 1998) is inferred for the paleoflora of the Molteno Formation.

The record of Late Triassic nonmarine tetrapods in marine strata, as reviewed by Lucas and Heckert (2000), also does not disagree with an early-mid Carnian age for the Ischigualastian. If not considered a nomen dubium (Sulej, 2002), the temnospondyl Metoposaurus santaecrucis from the upper part of the Raibler Schichten, Austria, suggests an early Carnian age (Lucas and Heckert, 2000; cf. Benton, 1994) for the European Ischigualastian faunas in which the genus occurs: Krasiejów and Blasensandstein. In addition, the indeterminate non-phytosaurid phytosaur Francosuchus trauthi (Hungerbühler, 1998; non-Paleorhinus Hunt and Lucas, 1991a) was recorded in the late Carnian marine deposits of the Opponitzer Schichten, Austria (Benton, 1994; Lucas and Heckert, 2000). In the biochronologic scheme proposed herein (Fig. 5), those basal phytosaurs occur in both Ischigualastian and post-Ischigualastian faunas, which indicates an ambiguous correlation between the Opponitzer Schichten and that LVF.

Lucas (1998a) dates the Ischigualasto Formation as late Carnian on the basis of its correlation with the Adamanian LVF. Indeed, some western North American deposits of the Otischalkian-Adamanian binomen seem to be of late Carnian age. On the basis of palynomorphs (Dunay and Fisher, 1974, 1979; Litwin et al., 1991), the Tecovas and Trujillo formations; Dockum Group (Texas) and the Shinarump-Blue Mesa Member sequence (Arizona and New Mexico) (Heckert and Lucas, 1997, 2003) were dated as Tuvalian. In addition, Lucas (1998a) mentions magnetostratigraphy and sequence stratigraphy studies of the lower Chinle Group that may support this inference.

A late Carnian age for the Otischalkian-Adamanian strata of western North America fits with the proposed correlation scheme, with the faunas of most of these deposits relatively younger than the Ischigualastian. In contrast to Heckert and Lucas (2002), the putative correlation between the North American Adamanian and the Ischigualastian is not enough to challenge the early Carnian radiometric dating of the latter. In turn, the lower position of the $227.8 \pm 0.3 \mathrm{Ma}$ old Ischigualasto Formation in relation to the late Carnian deposits of western North America supports the Triassic time scales proposed by Ross et al. (1994) and Gradstein and Ogg (1996), in contrast to Harland et al. (1990) and Kent and Olsen (1999).

As discussed by Olsen and Sues (1986), the Newark supergroup provides the most reliable guide for Late Triassic biostratigraphic studies involving the cross-correlation of palynology and vertebrate paleontology data. Two Carnian pollen zones have been recognized in the Newark supergroup - the Chatham-Richmond-Taylorsville and New Oxford-Lockatong-and given middle (Julian-early Tuvalian) and late (late Tuvalian) Carnian ages, respectively (Litwin et al., 1991; Cornet, 1993; cf. Olsen et al., 1996). The identification of these pollen zones in the Deep River and Gettysburg Basins (Cornet, 1977, 1993; Litwin and Ash, 1993) suggests ages from middle to late Carnian for the Pekin, Cumnock, and New Oxford Formations. Similarly, the Evangeline Member of the Wolfville Formation has been dated as late Carnian (Tuvalian) on the basis of palynomorphs (Fowell, 1994 in Olsen et al., 2000; cf. Olsen et al., 2003). These data fit with the proposed biostratigraphic scheme (Fig. 5), which is admittedly imprecise in the correlation of the tetrapod faunas of the North American Atlantic coast ('SanfordianConewagian' sensu Huber et al., 1993).

The 'Tectonostratigraphic Sequence II' of Olsen et al. (2000) includes strata from the Fundy Basin, Nova Scotia, and the Argana Basin, Morocco. It is considered Carnian in age, its lower part possibly extending into the Middle Triassic (Olsen et al., 2003). In Morocco, the Irohalene Member represents the upper third of that sequence, and its Tuvalian age is based on palynomorphs (Fowell, 1994 in Olsen et al., 2000; cf. Jalil, 1999), though magnetostratigraphic analyses assign an early Carnian age to the base of that stratigraphic unit (Olsen et al., 2002 based on the timescale of Kent et al., 1995). That stratigraphic unit therefore would represent the entire Carnian interval in the Argana Basin (Olsen et al., 2003). Accordingly, the fauna of its lower beds (Jalil, 1996) could characterize the earlier part of that stage and correspond to the early Ischigualastian, whereas the upper fauna would have a younger age, as proposed by the biostratigraphic scheme presented herein.

The dating of the putatively Ischigualastian fauna of the Blasensandstein at Ebrach challenges the early-middle Carnian age of that LVF. Lithostratigraphic studies have allowed its correlation with the Rote Wand and/or Kieselsandstein in Baden-Württemberg, Germany (Aigner and Bachmann, 1992), which tends to be dated as Late Carnian-Early Norian (see Benton, 1994). In turn, paleoclimatic evidence (Dockter et al., 1980 in Benton, 1994), based on the presence of evaporitic horizons with gypsum, suggests that these southern German strata are coeval with Tuvalian (late Carnian) marine deposits in Austria. As for the post-Ischigualastian faunas of south Pangea, Abdala et al. (2001) suggest a late Carnian age for the La Chilca fauna of the Los Colorados Formation, Argentina, according to the sedimentation rate of the Ischigualasto sequence. In addition, considering the early Carnian age of the Molteno Formation (Anderson and Anderson, 1983), the Lower Elliot Formation could be of late Carnian age, in accordance with its (at least partial) correlation with the South American Jachaleria-bearing strata.

\section{Conclusions}

The definition of the Ischigualastian LVF considerably improves the correlation of the Late Triassic continental 
deposits with tetrapods. It is based on the fauna of the Ischigualasto Formation, northwest Argentina, and its beginning and end are determined, respectively, by the FADs of the rhynchosaur Hyperodapedon and the dicynodont Jachaleria. Other than Hyperodapedon, the index fossils of the Ischigualastian include the traversodontid cynodont Exaeretodon, the aetosaur Aetosauroides, and herrerasaurid dinosaurs. This LVF is of prime use in the biochronologic correlation of the South American Late Triassic; its more direct coevals are tetrapod faunas from the Santa Maria sequence.

The Ischigualastian can be traced outside South America, especially throughout south Pangea. The tetrapod faunas that best correlate with it are those of the Pebbly Arkose Formation, Zimbabwe, and Lower Maleri Formation, India; that of the base of the Makay Formation, Madagascar, also might be coeval. However, fossil assemblages such as those of the Upper Elliot Formation, southern Africa, and Upper Maleri Formation, India, correspond to post-Ischigualastian faunal stages.

The assignment of the Ischigualastian faunas of south Pangea to a single LFV contradicts previous proposed tetrapod-based biochronologies (Lucas, 1998a) that place the faunas within a twofold scheme composed of the mutually exclusive Otischalkian and Adamanian LVFs. However, paleontological evidence for such a correlation is controversial, including doubtful records of index fossils whose taxonomic statuses are not clearly understood. For example, the Lower Maleri Formation was considered of Otischalkian age because of the occurrences of Paleorhinus and Metoposaurus, but it is uncertain if the phytosaur and metoposaur of that stratigraphic unit belong to those genera, which have yet to be comprehensively circumscribed. A younger Adamanian age proposed for the faunas of the Ischigualasto Formation and the Hyperodapedon assemblage zone of the Santa Maria Formation likewise is based on the putative record of poorly circumscribed taxa such as the aetosaur Stagonolepis in North America and the phytosaur Rutiodon in India. Moreover, dubious records based on fragmentary remains from western US have been used to back up these correlations, including the dicynodont Ischigualastia in the Los Esteros Member and the rauisuchian Saurosuchus in the Blue Mesa Member.

Otischalkian and Adamanian index fossils occur together in faunas such as those of the Placerias and Downs' quarries, Arizona, and Blasensandstein, Germany, as well as in those of the Upper Maleri Formation and Los Esteros Member. Thus, the Carnian biochronology in north Pangea can be refined to a threefold subdivision marked by the successive FADs of the phytosaurs Palaeorhinus, Leptosuchus, and Smilosuchus. The lower two of these faunal stages are coeval to the Ischigualastian, defined on the basis of the correlation with the Maleri sequence in India. The fauna of Krasiejów, the Blassensandstein, and the base of the Irohalene Member are given an early Ischigualastian age; those of the top of the Irohalene Member and various North American stratigraphic units-such as the Camp Springs Member and the Pekin, Cumnock, Popo Agie, and Lower Wolfville Formations-are equivalent to the late Ischigualastian. That of the Lossiemouth Sandstone Formation, is considered to be of undifferentiated Ischigualastian age.

Correlations based on continental tetrapods are problematic because of the often coarse biochronological information they provide. As discussed by Schultz (2004), the scarcity of fossils frequently leads to doubtful taxonomic interpretations that jeopardize the taxic approach to biostratigraphy. For the Late Triassic, the positive identification of index fossils, according to an updated taxonomic framework, is fundamental to the success of any biocronological enterprise.

\section{Acknowledgements}

Many colleagues improved this contribution with their expertise on Triassic biostratigraphy and/or the taxonomy of certain tetrapod groups, though they do not always agree with the ideas proposed herein. Drs Michael Benton and Sébastien Steyer reviewed the article as referees; Drs Claudia Marsicano, Julia Desojo, Axel Hungerbühler, and Fernando Abdala reviewed early versions. Crucial information was gently provided by Drs Claudia Marsicano, Cristina Vega-Dias, Julia Desojo, Robin Whatley, Axel Hungerbühler, Cesar Schultz, and Fernando Abdala.

\section{References}

Abdala, F., Giannini, N.P., 2000. Gomphodont cynodonts of the chañares formation: the analysis of an ontogenetic sequence. Journal of Vertebrate Paleontology 20, 501-506.

Abdala, F., Giannini, N.P., 2002. Chiniquodontid cynodonts: systematic and morphometric considerations. Palaeontology 45, 11511170 .

Abdala, F., Ribeiro, A.M., 2003. A new traversodontid cynodont from the Santa Maria formation, Ladinian-Carnian, of southern Brazil, with a phylogenetic analysis of Gondwanan traversodontids. Zoological Journal of the Linnean Society of London 139, 529-545.

Abdala, F., Ribeiro, A.M., Schultz, C.L., 2001. A rich cynodont fauna of Santa Cruz do Sul, Santa Maria Formation, Middle-Late Triassic, Southern Brazil. Neues Jahrbuch für Geologie und Paläontologie, Monatshefte 2001;, 669-687.

Abdala, F., Barberena, M.C., Dornelles, J.F., 2002. A new species of the traversodontid cynodont exaeretodon from the Santa Maria formation, middle/late triassic, of southern Brazil. Journal of Vertebrate Paleontology 22, 313-325.

Agassiz, L.J.R., 1844. Monographie des poissons fossiles du vieux grès rouge ou système Dévonien (Old Red sandstone) des Iles britanniques et de Russie. Neuchâtel, 171 pp.

Aigner, T., Bachmann, G.H., 1992. Sequence-stratigraphic framework of the German Triassic. Sedimentary Geology 80, 115-135.

Alcober, O., 2000. Redescription of the skull of Saurosuchus galilei (Archosauria: Rauisuchidae). Journal of Vertebrate Paleontology 20, 302-316. 
Anderson, J.M., 1981. World permo-triassic correlations: their biostratigraphic basis. In: Cresswell, M.M., Vella, P. (Eds.), Gondwana fiveprocedings of the fifth international gondwana symposium (Wellington). A.A. Balkema, pp. 3-10.

Anderson, J.M., Anderson, H.M., 1983. Paleoflora of Southern Africa: Molteno Formation (Triassic): Part 1, Introduction; Part 2, Dicroidium, vol. 1. A.A. Balkema.

Anderson, J.M., Anderson, H.M., 1993. Terrestrial flora and fauna of the Gondwana Triassic: Part 1—occurrences. In: Lucas, S.G., Morales, M. (Eds.), The Nonmarine Triassic. Bulletin of the New Mexico Museum of Natural History and Sciences 3, pp. 3-12.

Anderson, J.M., Anderson, H.M., Cruickshank, A.R.I., 1998. Late triassic ecosystems of the molteno/lower elliot biome of southern Africa. Palaeontology 41, 387-422.

Araújo, D.C., Gonzaga, T.D., 1980. Uma nova espécie de Jachaleria (Therapsida Dicynodontia) do Triassico do Brasil. II Congreso Argentino de Paleontología y Biostratigrafía/I Congreso Latinoamericano de Paleontología (Buenos Aires). Actas 1980;, 159-174.

Azevedo, S.A.K., Schultz, C.L., Barberena, M.C., 1990. Novas evidências biostratigráficas e paleoecológicas na análise de evolução explosiva dos rincossauros do Triássico. Paula-Coutiana 4, 23-33.

Baird, D., 1963. Rhynchosaurs in the late triassic of nova scotia, Geological Society of America, Special Papers 731963 p. 107.

Baird, D., 1986. Some upper Triassic reptiles, footprints and an amphibian from New Jersey, The Mosasaur 31986 pp. 125-153.

Barberena, M.C., 1974. Contribuição ao conhecimento dos cinodontes gonfodontes (Cynodontia, Tritylodontoidea) do Brasil. Livre Docencia thesis, Instituto de Geociências, UFRGS, Porto Alegre, 194.

Barberena, M.C., Araújo, D.C., Lavina, E.L., 1985a. Late Permian and Triassic tetrapods of southern Brazil. National Geographic Research 1, 5-20.

Barberena, M.C., Araújo, D.C., Lavina, E.L., Azevedo, S.A.K., 1985b. O estado atual do conhecimento sobre os tetrápodes permianos e triássicos do Brasil meridional. In: MME/DNPM, Coletânea de Trabalhos Paleontológicos, Série Geologia 27(2), pp. 21-28.

Benton, M.J., 1983a. Dinosaur success in the Triassic: a noncompetitive ecological model. The Quarterly Review of Biology 58, 29-55.

Benton, M.J., 1983b. The Triassic reptile Hyperodapedon from Elgin: functional morphology and relationships. Philosophical Transactions of the Royal Society of London, Series B 302, 605-717.

Benton, M.J., 1994. Late Triassic to Middle jurassic extintions among continental tetrapods: testing the pattern. In: Fraser, N.C., Sues, H.-D. (Eds.), In the Shadow of the Dinosaurs. Cambridge University Press, Cambridge, pp. 366-397.

Benton, M.J., Clark, J., 1988. Archosaur phylogeny and the relationships of the Crocodylia. In: Benton, M.J. (Ed.), The Phylogeny and Classification of the Tetrapods. Systematics Association Special Volume 35A, pp. 295-338.

Benton, M.J., Walker, A.D., 1985. Palaeoecology, taphonomy, and dating of Permo-Triassic reptiles from Elgin, north-east Scotland. Palaeontology 28, 207-234.

Bonaparte, J.F., 1962. Descripción del craneo y mandibula de Exaeretodon frenguellii Cabrera y su comparición con Diademodontidae, Tritylodontidae y los cinodontes sudamericanos. Publicación del Museo Municipal de Ciencias Naturales y Tradicional de Mar del Plata 1 (5), $135-202$.

Bonaparte, J.F., 1963a. Promastodonsaurus bellmanni n. gen. et n. sp., capitosáurido del Triásico medio de Argentina (StereospondyliCapitosauroidea). Ameghiniana 3, 67-78.

Bonaparte, J.F., 1963b. Descripción de Ischignathus sudamericanus n. gen. n. sp., nuevo cindonte gonfodonte del Triásico Medio Superior de San Juan, Argentina (Cynodontia-Traversodontidae). Acta Geológica Lilloana 4, 111-128.

Bonaparte, J.F., 1966. Chronological survey of the tetrapod bearing Triassic of Argentina. Breviora 251, 1-13.

Bonaparte, J.F., 1971. Annotated list of the South American Triassic tetrapods. In: Haughton, S.H. (Ed.), Second Gondwana Symposium,
Proceedings and Papers. Council of Scientific and Industrial Research, Pretoria, pp. 665-682.

Bonaparte, J.F., 1973. Edades reptil para el Triássico de Argentina y Brasil. 5 Congreso Geologico Argentino (Córdoba). Actas 3, 93-129.

Bonaparte, J.F., 1975. Sobre la presencia del laberintodonte Pelorocephalus en la Formación Ischigualasto y su significado estratigráfico (Brachyoidea-Chigutisauridae). I Congreso Argentino de Paleontogia y Estratigtafia (Tucumán). Actas 1, 537-544.

Bonaparte, J.F., 1976. Pisanosaurus mertii Casamiquela and the origin of the Ornithischia. Journal of Paleontology 50, 808-820.

Bonaparte, J.F., 1981. Descripcion de Fasolasuchus tenax y su significado en la sistematica y evolucion de los Thecodontia. Revista del Museo Argentino de Ciencias Naturales Bernardino Rivadavia 3, 55-101.

Bonaparte, J.F., 1982. Faunal replacement in the Triassic of South America. Journal of Vertebrate Paleontology 2, 362-371.

Bonaparte, J.F., 1997. El Triassico de San Juan-La Rioja Argentina y sus dinosaurios. Museo Argentino de Ciências Naturales, Buenos Aires, $174 \mathrm{pp}$.

Bonaparte, J.F., Crompton, A.W., 1994. A juvenile probainognathid cynodont skull from the Ischigualasto Formation and the origin of mammals. Revista del Museo Argentino de Ciencias Naturales Bernardino Rivadavia 5, 1-12.

Bond, G., 1973. The paleontology of Rhodesia. Bulletin of the Geological Survey of Rhodesia 70, 1-121.

Boonstra, L.D., 1953. A note on some rhynchosaurian remains from Tanganyika Territory. Annals of the South African Museum 42, 1-4.

Burmeister, K.C., Flynn, J.J., Parrish, J.M., Whatley, R.L., Wyss, A.R., 2000. Biostratigraphic and biogeographic implications of new middle to Late Triassic fossil vertebrates; Morondava Basin, Madagascar: 2000 Meeting of the Western Association of Vertebrate Paleontologists, Abstracts. Flagstaff, AZ.

Casamiquela, R.M., 1960. Noticia preliminar sobre dos nuevos estagonolepoideos argentinos. Ameghiniana 2, 3-9.

Case, E.C., 1931. Description of a new species of Buettneria with a discussion of the brain case. Contributions from the Museum of Paleontology, University of Michigan 3, 187-206.

Caselli, A.T., Marsicano, C.A., Arcucci, A.B., 2001. Sedimentologia y paleontologia de la Formacion Los Colorados, Triasico superior (provincias de La Rioja y San Juan, Argentina). Revista de la Asociacion Geológica Argentina 56, 173-188.

Chatterjee, S., 1974. A rhynchosaur from the upper Triassic Maleri Formation of India. Phylosophical Transactions of the Royal Society of London, Series B 276, 209-261.

Chatterjee, S., 1978. A primitive parasuchid (phytosaur) reptile from the Upper Triassic Maleri Formation of India. Palaeontology 21, 83-127.

Chatterjee, S., 1980a. The evolution of rhynchosaurs. Mémoires de la Societé Géologique de France 139, 57-65.

Chatterjee, S., 1980b. Melerisaurus, a new eosuchian reptile from the Late Triassic of India. Phylosophical Transactions of the Royal Society of London, Series B 291, 163-200.

Chatterjee, S., 1982. A new cynodont reptile from the Triassic of India. Journal of Paleontology 56, 203-214.

Chatterjee, S., 1987. A new theropod dinosaur from India with remarks on the Gondwana-Laurasia connection in the Late Triassic. In: McKenzie, G.D. (Ed.), Gondwana Six: Stratigraphy, Sedimentology and Paleontology Geophysical Monographs 41, pp. 183-189.

Chatterjee, S., Hotton III., N., 1986. The paleoposition of India. Journal of Southeast Asian Earth Sciences 1, 145-189.

Chatterjee, S., Scotese, C.R., 1999. The breakup of Gondwana and the evolution and biogeography of the Indian plate. Proceedings of the Indian National Science Academy 65A (3), 397-425.

Contreras, V.H., 1981. Datos preliminares sobre un nuevo rincossaurio (Reptilia Rhynchosauria) del Triássico superior de Argentina. II Congresso Latino-Americano de Paleontologia (Porto Alegre). Anais 1981;, 289-294. 
Contreras, V.H., Bracco, A., Sill, W., 1997. Primer registro de restos de tetrápodos en la Formación Los Rastros (Triásico Medio), Parque Provincial Ischigualasto, San Juan, Argentina. Ameghiniana 34, 534.

Cooper, M.R., 1982. A Mid-Permian to earliest Juarssic tetrapod biostratigraphy and its significance. Arnoldia, Zimbabwe 9, 77-103.

Cornet, B., 1977. The palynostratigraphy and age of the Newark Supergroup. PhD Thesis, Pennsylvania State University, 506 pp.

Cornet, B., 1993. Applications and limitations of palynology in age, climatic, and paleoenvironmental analyses of Triassic sequences in North America. In: Lucas, S.G., Morales, M. (Eds.), The Nonmarine Triassic Bulletin of the New Mexico Museum of Natural History and Science 3, pp. 75-93.

Cox, C.B., 1965. New Triassic dicynodonts from South America, their origins and relationships. Philosophical Transactions of the Royal Society of London, Series B 248, 457-516.

Damiani, R.J., 2001. A systematic revision and phylogenetic analysis of Triassic mastodonsauroids (Temnospondyli: Stereospondyli). Zoological Journal of the Linnean Society 133, 379-482.

Desojo, J.B., 1999. Los aetosaurios (Reptilia Archosauria) sudamericanos: su status taxonómico. Ameghiniana 36, 10R.

Doyle, K.D., Sues, H.-D., 1995. Phytosaurs (Reptilia: Archosauria) from the upper Triassic New Oxford formation of York county, Pennsylvania. Journal of Vertebrate Paleontology 15, 545-553.

Dunay, R.E., Fisher, M.J., 1974. Late Triassic palynofloras of North America and their European correlatives. Reviews of Palaeobotany and Palynology 17, 179-186.

Dunay, R.E., Fisher, M.J., 1979. Palynology of the Dockum Group (Upper Triassic), Texas, USA. Reviews of Palaeobotany and Palynology 28, 61-92.

Dzik, J., 2001. A new Paleorhinus fauna in the Early Late Triassic of Poland. Journal of Vertebrate Paleontology 21, 625-627.

Dzik, J., 2003. A beaked herbivorous archosaur with dinosaur affinities from the Early Late Triassic of Poland. Journal of Vertebrate Paleontology 23, 556-574.

Faccini, U.F., 1989. O Permo-Triássico do Rio Grande do Sul: uma análise sob o ponto de vista das seqüencias deposicionais. MSc Thesis, Instituto de Geociências, UFRGS, Porto Alegre, 212 pp.

Fara, E., Hungerbühler, A., 2000. Paleorhinus magnoculus from the Upper Triassic of Morocco: a juvenile primitive phytosaur. Comptes Rendus de l'Academie des Sciences, Paris 331, 831-836.

Flynn, J.J., Parrish, J.M., Wyss, A.R., Simson, W.F., 1998. New Triassic and Jurrasic vertebrates from Madagascar. Journal of Vertebrate Paleontology 18 (suppl. to number 3), 42A.

Flynn, J.J., Parrish, J.M., Rakotosamimanana, B., Simson, W.F., Whatley, R.L., Wyss, A.R., 1999. A Triassic fauna from Madagascar, including early dinosaurs. Science 286, 763-765.

Flynn, J.J., Parrish, J.M., Rakotosamimanana, B., Simson, W.F., Wyss, A.R., 2000. New traversodontids (Synapsida: Eucynodontia) from the Triassic of Madagascar. Journal of Vertebrate Paleontology 20, 422-427.

Fraser, N.C., Benton, M.J., 1989. The Triassic reptiles Brachyrhinodon and Polysphenodon and the relationships of the sphenodontids. Zoological Journal of the Linnean Society of London 96, 413-445.

Galton, P.M., Heerden, J. van, 1998. Anatomy of the prosauropod dinosaur Blikanasaurus cromptoni (Upper Triassic, South Africa), with notes on the other tetrapods from the lower Elliot Formation. Paläontologische Zeitschrift 72, 163-177.

Gauffre, F.-X., 1993a. The prosauropod dinosaur Azendohsaurus laaroussi from the Upper Triassic of Marocco. Palaeontology 36, 897-908.

Gauffre, F.-X., 1993b. Biochronostratigraphy of the Lower Elliot Formation, southern Africa) and preliminary results on the Maphutseng dinosaur, Saurischia: Prosauropoda, from the same Formation of Lesotho. In: Lucas, S.G., Morales, M. (Eds.), The Nonmarine Triassic Bulletin of the New Mexico Museum of Natural History and Science 3, pp. 147-149.
Godefroit, P., 1999. New traversodontid (Therapsida: Cynodontia) teeth from the Upper Triassic of Habay-la-Vieille (southern Belgium). Paläontologische Zeitschrift 73, 385-394.

Godefroit, P., Battail, B., 1997. Late Triassic cynodonts from SaintNicolas-de-Port (north-eastern France). Geodiversitas 19, 567-631.

Gradstein, F.M., Ogg, J., 1996. A Phanerozoic time scale. Episodes 19, 3-5.

Hahn, G., Lepage, J.-C., Wouters, G., 1988. Traversodontiden-Zähne (Cynodontia) aus der Ober-Trias von Gaume (Süd-Belgien). Bulletin de 1'Institut Royal des Sciences Naturelles de Belgique, Sciences de la Terre 58, 177-186.

Hancox, P.J., 2000. The continental Triassic of South Africa. Zentralblatt für Geologie und Paläontologie Teil I 1998, 1285-1324.

Hankel, O., 1987. Lithostratigraphic subdivision of the Karroo rocks of the Luwegu Basin (Tanzania) and their biostratigraphic classification based on microfloras, macrofloras, fossil woods and vertebrates. Geologische Rundschau 72 (2), 538-565.

Harland, W.B., Armstrong, R.L., Cox, A.V., Craig, L.E., Smith, A.G., Smith, D.G., 1989. A geologic time scale 1989. Cambridge University Press p. 263.

Harris, S.K., Heckert, A.B., Lucas, S.G., Hunt, A.P., 2002. The oldest North American prosauropod, from the upper triassic tecovas formation of the chinle group (Adamanian: latest carnian) West Texas. In: Heckert, A.B., Lucas, S.G. (Eds.), Upper Triassic Stratigraphy and Paleontology Bulletin of the New Mexico Museum of Natural History and Sciences 21, pp. 249-252.

Harris, S.R., Gower, D.J., Wilkinson, M., 2003. Intraorganismal homology, character construction and the phylogeny of aetosaurian archosaurs (Reptilia, Diapsida). Systematic Biology 52, 239-252.

Heckert, A.B., Lucas, S.G., 1997. Lower chinle group (Adamanian: latest carnian) tetrapod biostratigraphy and biochronology, eastern Arizona and west-central new Mexico. Southwest Paleontological Symposium Proceedings 1997; 11-23.

Heckert, A.B., Lucas, S.G., 1999. A new aetosaur (Reptilia:Archosauria) from the Upper Triassic of Texas and the phylogeny of aetosaurs. Journal of Vertebrate Paleontology 19, 50-68.

Heckert, A.B., Lucas, S.G., 2000. Taxonomy, phylogeny, biostratigraphy, biochronology, paleobiogeography, and evolution of the Late Triassic Aetosauria (Archosauria:Crurotarsi). Zentralblatt für Geologie und Paläontologie Teil I 11-12, 1539-1587.

Heckert, A.B., Lucas, S.G., 2002. South American occurrences of the Adamanian (Late Triassic:Latest Carnian) index taxon Stagonolepis (Archosauria:Aetosauria) and their biochronological significance. Journal of Paleontology 76, 852-863.

Heckert, A.B., Lucas, S.G., 2003. Revised upper triassic stratigraphy of the petrified forest national park, USA. In: Heckert, A.B., Lucas, S.G. (Eds.), Upper Triassic Stratigraphy and Paleontology Bulletin of the New Mexico Museum of Natural History and Sciences 21, pp. 1-36.

Heckert, A.B., Lucas, S.G., Hunt, A.P., 1996. Redescription of Redondasuchus reseri, a Late Triassic aetosaur (Reptilia: Archosauria) from New Mexico (USA.) and the biochronology and phylogeny of aetosaurs. Geobios 29, 619-632.

Heckert, A.B., Lucas, S.G., Krzyzanowski, S.E., 2002. The rauisuchian archosaur Saurosuchus from the upper Triassic Chinle Group, southwestern USA, and its biochronologic signifcance. In: Heckert, A.B., Lucas, S.G. (Eds.), Upper Triassic Stratigraphy and Paleontology Bulletin of the New Mexico Museum of Natural History and Sciences 21, pp. 241-244.

Heerden, J. van, 1979. The morphology and taxonomy of Euskelosaurus (Reptilia: Saurischia; Late Triassic) from South Africa. Navorsinge van die Nasionale Museum, Bloemfontein 4, 21-84.

Heredia, G.J., Trotteyn, M.J., Correa, G., Fernandez, E., Castagna, U., 2004. Primer cinodonte traversodóntido (Cynodontia-Trytilodontoidea) de la Formación Los Colorados (Triásico superior-Noriano), Consideraciones biocronológicas. XX Jornadas Argentinas de Paleontologia de Vertebrados, (La Plata), Resumenes 12004 p.34.

Hopson, J.A., 1984. Late Triassic traversodont cynodonts from Nova Scotia and southern Africa. Palaeontologia Africana 25, 181-201. 
Hopson, J.A., 1985. Morphology and relationships of Gomphodontosuchus brasiliensis von Huene (Synapsida Cynodontia, Tritylodontoidea) from the Triassic of Brazil. Neues Jahrbuch für Geologie und Paläontologie, Monastshefte 1985; 285-299.

Huber, P., Lucas, S.G., Hunt, A.P., 1993. Vertebrate biochronology of the Newark Supergroup Triassic, eastern North America. In: Lucas, S.G., Morales, M. (Eds.), The Nonmarine Triassic New Mexico Museum Natural History Science Bulletin 3, pp. 179-186.

Huene, F. von, 1935-1942. Die fossilen Reptilien des südamerikanischen Gondwanalandes. C.H. Beck, Munich, 332 pp.

Hungerbühler, A., 1998. Cranial anatomy and diversity of the Norian phytosaurs from southwest Germany. PhD Thesis, University of Bristol, 464 pp.

Hungerbühler, A., 2001. Status and phylogenetic relationships of the Late Triassic phytosaur Rutiodon carolinensis. Journal of Vertebrate Paleontology 21, 64A.

Hungerbühler, A., Chatterjee, S., 2002. New phytosaurs from the Upper Triassic of India. Journal of Vertebrate Paleontology 22, 68A.

Hunt, A.P., 1993. Revision of the Metoposauridae (Amphibia: Temnospobdyli) and description of a new genus from Western North America. In: Morales, M. (Ed.), Aspects of Mesozoic Geology and paleontology of the Colorado Plateau Museum of Northern Arizona Bulletin 59, pp. 67-97.

Hunt, A.P., Lucas, S.G., 1990. Re-evaluation of Typothorax meadei, a Late Triassic aetosaur from the United States. Paläontologische Zeitschrift 64, 317-328.

Hunt, A.P., Lucas, S.G., 1991a. The Paleorhinus biochron and the correlation of the non-marine Upper Triassic of Pangea. Palaeontology 34, 487-501.

Hunt, A.P., Lucas, S.G., 1991b. A new rhynchosaur from West Texas (USA) and the biochronology of Late Triassic rhynchosaurs. Palaeontology 34, 927-938.

Hunt, A.P., Lucas, S.G., 1993. Triassic vertebrate paleontology and biochronology of New Mexico. In: Lucas, S.G., Morales, M. (Eds.), The Nonmarine Triassic Bulletin of the New Mexico Museum of Natural History and Science 3, pp. 49-60.

Jalil, N.-E., 1996. Les vertébrés permiens et triasiques de la formation d'Argana (Haut Atlas occidental): liste faunique préliminaire et implications stratigraphiques. In: Medina, F. (Ed.), Le Permien et le Trias du Maroc: état des connaissances. Pumag, Marrakesh, pp. 227-250.

Jalil, N.-E., 1999. Continental Permian and Triassic vertebrate localities from Algeria and Morocco and their stratigraphical correlations. Journal of African Earth Sciences 29, 219-226.

Jalil, N.-E., Knoll, F., 2002. Is Azendohsaurus laaroussii (Carnian, Morocco) a dinosaur?. Journal of Vertebrate Paleontology 22 (Suppl. to number 3), 70A.

Jalil, N.-E., Hunt, A.P., Lucas, S.G., 1995. Late Triassic aetosaurs and phytosaur from Algeria. Neues Jahrbuch für Geologie und Paläontologie, Monatshefte 3, 173-181.

Kaye, T., Padian, K., 1994. Microvertebrates from the Placerias Quarry: a window on Late Triassic vertebrate diversity in the American Southwest. In: Fraser, N.C., Sues, H.-D. (Eds.), In the Shadow of the Dinosaurs. Cambridge University Press, Cambridge, pp. 171-196.

Kent, D.V., Olsen, P.E., 1999. Astronomically tuned geomagnetic polarity time scale for the Late Triassic. Journal of Geophysical Research 104, 12831-12841.

Kent, D.V., Olsen, P.E., Witte, W.K., 1995. Late Triassic-Earliest Jurassic geomagnetic polarity sequence and paleolatitudes from drill cores in the Newark rift basin, eastern North America. Journal of Geophysical Research 100, 14965-14998.

Kitching, J.W., Raath, M.A., 1984. Fossils from the Elliot and Clarens Formations (Karoo sequence) of the northeastern cape, orange free state and lesotho, and a suggested biozonation based on tetrapods. Palaeontologia Africana 25, 111-125.
Kuhn, O., 1932. Labyrinthodonten und Parasuchier aus dem mittleren Keuper von Ebrach in Oberfranken Neues Jahrbuch für Mineralogie. Geologie und Paläontologie, Abteilung B 69, 94-144.

Kuhn, O., 1936. Weitere Parasuchier und Labyrinthodonten aus dem Blasensandstein des mittleren Keuper von Ebrach. Palaeontographica 83, 61-98.

Kutty, T.S., Sengupta, D.P., 1989. The Late Triassic Formations of the Pranhita-Godavary Valley and their vertebrate faunal succession-a reappraisal. Indian Journal of Earth Sciences 16, 189-206.

Kutty, T.S., Jain, S.L., Roy-Chowdhury, T., 1987. Gondwana sequence of Northern Pranhita-Godavari Valley: its stratigraphy and vertebrate faunas. The Palaeobotanist 36, 263-282.

Langer, M.C., 2004. Basal saurischians. In: Weishampel, D., Dodson, P., Osmólska, H. (Eds.), The Dinosauria, second ed. University of California Press, Berkeley, pp. 25-46.

Langer, M.C., 2005. Studies on continental Late Triassic tetrapod biochronology. I. The type locality of Saturnalia tupiniquim and the faunal succession in South Brazil. Journal of South American Earth Sciences 19, 205-218.

Langer, M.C., Schultz, C.L., 2000. A new species of the Late Triassic rhynchosaurs Hyperodapedon from the Santa Maria Formation of South Brazil. Palaeontology 43, 633-652.

Langer, M.C., Abdala, N.F., Richter, M., Benton, M.J., 1999. A sauropodomorph dinosaur from the Upper Triassic, Carnian) of southern Brazil. Comptes Rendus de l'Academie des Sciences, serie II, fascicule A, Sciences de la Terre e des Planetes 329, 511-517.

Langer, M.C., Boniface, M., Cuny, G., Barbieri, L., 2000. The phylogentic position of Isalorhynchus genovefae, a Late Triassic rhynchosaur from Madagascar. Annales de Palelontologie 86, 101-127.

Litwin, R.J., Ash, S.R., 1993. Revision of the biochronology of the chatham group (upper Triassic), deep river basin, North Carolina. Reviews of Palaeobotany and Palynology 77, 75-95.

Litwin, R.J., Traverse, A., Ash, S.R., 1991. Preliminary palinological zonation of the Chinle formation, southwestern USA and its correlation to the Newark Supergroup (eastern USA). Reviews of Paleobotany and Palynology 68, 269-287.

Long, R.A., Ballew, K.L., 1985. Aetosaur dermal armor from the late Triassic of southwestern North America, with special reference to material from the Chinle formation of petrified forest national park. Museum of Northern Arizona Bulletin 47, 45-68.

Long, J.A., Murry, P.A., 1995. Late Triassic (Carnian and Norian) tetrapods from the Southwestern United States. Bulletin of the New Mexico Museum of Natural History and Science 4, 1-254.

Lucas, S.G., 1991. Sequence stratigraphic correlation of nonmarine and marine Late Triassic biochronologies, western USA. Albertiana 9, 11-18.

Lucas, S.G., 1994. The beginning of the age of dinosaurs in Wyoming. Wyoming Geological Association Guidebooks 44, 105-113.

Lucas, S.G., 1998a. Global Triassic tetrapod biostratigraphy and biochronology. Palaeogeography, Palaeoclimatology, Palaeoecology 143, 347-384.

Lucas, S.G., 1998b. The aetosaur Longosuchus from the Triassic of Morocco and its biochronologic significance. Comptes Rendus de l'Academie des Sciences, Paris 326, 589-594.

Lucas, S.G., 1998c. Placerias (Reptilia, Dicynodontia) from the Upper Triassic of the Newark Supergroup, North Carolina, USA, and its biochronological significance. Neues Jahrbuch für Geologie und Paläontologie, Monatshefte 1998;, 432-448.

Lucas, S.G., 2003. A new dicynodont from the Triassic o Brazil, and the tetrapod biochronology of the Brazilian Triassic. Bulletin of the New Mexico Museum of Natural History and Science 21, 131-141.

Lucas, S.G., Hancox, P.J., 2001. Tetrapod-based correlation of the nonmarine upper Triassic of Southern Africa. Albertiana 25, 5-9.

Lucas, S.G., Heckert, A.B., 1996. Late Triassic aetosaur biochronology. Albertiana 17, 57-64.

Lucas, S.G., Heckert, A.B., 2000. Biochronologic significance of Triassic nonmarine tetrapod records from marine strata. Albertiana 24, 30-36. 
Lucas, S.G., Heckert, A.B., 2001. The aetosaur Stagonolepis from the upper Triassic of Brazil and its biochronologic significance. Neues Jahrbuch für Geologie und Paläontologie, Monatshefte 2001;, 719-732.

Lucas, S.G., Heckert, A.B., 2002. The Hyperodapedon Biochron, late Triassic of Pangea. Albertiana 27, 30-38.

Lucas, S.G., Hunt, A.P., 1992. Triassic stratigraphy and paleontology, Chama basin and adjacent areas, north-central New Mexico. New Mexico Geologic Society Guidebook 43, 151-172.

Lucas, S.G., Hunt, A.P., 1993a. Tetrapod biochronology of the Chinle group (Upper Triassic), western United States. In: Lucas, S.G., Morales, M. (Eds.), The Nonmarine Triassic New Mexico Museum of Natural History and Science 3, pp. 327-329.

Lucas, S.G., Hunt, A.P., 1993b. A dicynodont from the upper Triassic of New Mexico and its biochronologic significance. In: Lucas, S.G., Morales, M. (Eds.), The Nonmarine Triassic New Mexico Museum of Natural History and Science 3, pp. 321-325.

Lucas, S.G., Hunt, A.P., 1994. The chronology and paleobiogeography of mammalian origins. In: Fraser, N.C., Sues, H.-D. (Eds.), In the Shadow of the Dinosaurs. Cambridge University Press, Cambridge, pp. 335-351.

Lucas, S.G., Wild, R., 1995. A middle Triassic dicynodont from Germany and the biochronology of Triassic dicynodonts. Stuttgarter Beiträge zur Naturkunde 220, 1-16.

Lucas, S.G., Hunt, A.P., Kahle, R.W., 1993. Late Triassic vertebrates from the Dockum Formation near Otis Chalk. Howard County, Texas. New Mexico Geological Society Guidebook 44, 237-244.

Lucas, S.G., Heckert, A.B., Hunt, A.P., 1997. Stratigraphy and biochronologic significance of the Late Triassic Placerias quarry, eastern Arizona (USA). Neues Jahrbuch für Geologie und Paläontologie, Abhandlungen 203, 23-46.

Lucas, S.G., Heckert, A.B., Hotton III., N., 2002a. The rhynchosaur Hyperodapedon from the upper Triassic of Wyoming and its global biochronological significance. In: Heckert, A.B., Lucas, S.G. (Eds.), Upper Triassic Stratigraphy and Paleontology Bulletin of the New Mexico Museum of Natural History and Sciences 21, pp. 149-156.

Lucas, S.G., Heckert, A.B., Kahle, R., 2002b. Postcranial anatomy of Angistorhynus, a late Triassic phytosaurs from West Texas. In: Heckert, A.B., Lucas, S.G. (Eds.), Upper Triassic Stratigraphy and Paleontology. Bulletin of the New Mexico Museum of Natural History and Sciences, vol. 21, pp. 157-164.

Marsicano, C.A., 1999. Chigutisaurid amphibians from the upper Triassic of Argentina and their phylogenetic relationships. Palaeontology 42, $1-21$.

Marsicano, C.A., Arcucci, A., 2002. Anexo 8, Vertebrados. In: Stipanicic, P.N., Marsicano, C.A. (Eds.), Léxico Estratigráfico de la Argentina, vol. 3. Triásico, Buenos Aires, pp. 327-330.

Martinez, R.N., Forster, C., 1996. The skull of Probelesodon sanjuanensis sp. nov. from the Late Triassic Ischigualasto Formation of Argentina. Journal of Vertebrate Paleontology 16, 285-291.

Martinez, R.N., May, C.L., Forster, C., 1996. A new carnivorous cynodont from the Ischigualasto Formation (Late Triassic) with comments on eucynodont phylogeny. Journal of Vertebrate Paleontology 16, 271284.

Martz, J., Mueller, B., Small, B., 2003. Two new aetosaurs (Archosauria: Stagonolepididae) from the Upper Triassic of Texas and Colorado, and problems in aetosaur identificaton and taxonomy. Journal of Vertebrate Paleontology 23 (supl. to vol. 3), 76A.

Milana, J.P., 2002. Ischigualasto (Secuencia). In: Stipanicic, P.N., Marsicano, C.A. (Eds.), Léxico Estratigráfico de la Argentina, vol. 8. Triásico, Buenos Aires, p. 149.

Milana, J.P., Alcober, O., 1995. Modelo tectosedimentario de la cuenca triásica de Ischigualasto, San Juan, Argentina. Revista de la Asociación Geológica Argentina 49, 217-235.

Milner, A.R., 1994. Late Triassic and Jurassic amphibians: fossil record and phylogeny. In: Fraser, N.C., Sues, H.-D. (Eds.), In the Shadow of the Dinosaurs. Cambridge University Press, Cambridge, pp. 5-22.
Morel, E.M., Artabe, A.E., 2002. Cortaderitiano (piso). In: Stipanicic, P.N., Marsicano, C.A. (Eds.), Léxico Estratigráfico de la Argentina, vol. 8. Triásico, Buenos Aires, pp. 106-107.

Murry, P.A., Long, R.A., 1989. Geology and paleontology of the chinle formation, petrified forest national park and vicinity, Arizona and a discussion of vertebrate fossils of the southwestern upper Triassic. In: Lucas, S.G., Hunt, A.P. (Eds.), The Dawn of the Age of Dinosaurs in the American Southwest New Mexico Museum of Natural History, pp. 29-64.

Novas, F.E., 1993. New information on the systematics and postcranial skeleton of Herrerasaurus ischigualastensis (Theropoda: Herrerasauridae) from the Ischigualasto Formation (Upper Triassic) of Argentina. Journal of Vertebrate Paleontology 13, 400-423.

Ochev, V.G., Shishkin, M.A., 1989. On the principles of global correlation of the continental Triassic on the tetrapods. Acta Palaeontologica Polonica 34, 149-173.

Oesterlen, P.M., Millsteed, B.D., 1994. Lithostratigraphy, palaeontology, and sedimentary environments of the western Cabora Bassa Basin, Lower Zambezi Valley, Zimbabwe. South African Journal of Geology 97, 205-224.

Olsen, P.E., Galton, P.M., 1984. A review of the reptile and amphibian assemblages from the Stormberg of southern Africa, with special emphasis on the footprints and the age of the Stormberg. Palaeontologia africana, Haughton Memorial Volume 1984;, 92-116.

Olsen, P.E., Sues, H.-D., 1986. Correlation of the continental Late Triassic and early Jurassic sediments, and patterns of the Triassic-Jurassic tetrapod transition. In: Padian, K. (Ed.), The Beginning of the Age of Dinosaurs, Faunal Change Across the Triassic-Jurassic Boundary. Cambridge University Press, New York, pp. 321-351.

Olsen, P.E., Kent, D.V., Cornet, B., Witte, W.K., Schlische, R.W., 1996. High-resolution stratigraphy of the Newark rift basin (Early Mesozoic, Eastern North America). Geological Society of America Bulletin 108, 40-77.

Olsen, P.E., Kent, D.V., Fowell, S.J., Schlische, R.W., Withjack, M.O., LeTourneau, P.M., 2000. Implications of a comparison of the stratigraphy and depositional environments of the Argana (Morocco) and Fundy (Nova Scotia, Canada) Permian-Jurassic basins. In: Oujidi, M., Et-Touhami, M. (Eds.), Le Permien et le Trias du Maroc Actes de la Premièr Réunion su Groupe Marocain du Permien et du Trias (Oujda). Hilal Impression, pp. 165-183.

Olsen, P.E., Kent, D.V., Et-Touhami, M., Fowell, S.J., Witte, B., 2002. Cyclycity, time scale, and correlation of the Triassic and Early Jurassic rift strata of the Argana Basin, Morocco. In: Essamoud, R., Ekamel, F. (Eds.), Troisème Réunion du Groupe Marocain du Permien et du Trias (Casablanca), Résumés, pp. 29-30.

Olsen, P.E., Kent, D.V., Et-Touhami, M., 2003. Chronology and stratigraphy of the Fundy and related Nova Scotia offshore basins and Morocco based on core and outcrop. In: Brown, D. (Ed.), Conventional Core Workshop, Geological Society of America (NE Section) and Atlantic Geoscience Society (Halifax), pp. 51-63.

Parrish, J.M., 1994. Cranial osteology of Longosuchus meadei and the phylogeny and distribution of the Aetosauria. Journal of Vertebrate Paleontology 14, 196-209.

Raath, M., 1996. Earliest evidence of dinosaurs from Central Gondwana. Memoirs of the Queensland Museum 39, 703-709.

Raath, M., Oesterlen, P.M., Kitching, J.W., 1992. The first record of Triassic Rhynchosauria (Reptilia: Diapsida) from the Lower Zambezi Valley, Zimbabwe. Palaeontologia Africana 29, 1-10.

Ray, S., Chimsamy, A., 2002. A theropod tooth from the Late Triassic of southern Africa. Journal of Biosciences 27, 295-298.

Razafimbelo, M.E., 1987. Le basin de Morondava (Madagascar) synthèse géologique et structurale. $\mathrm{PhD}$ Thesis. Université Louis Pasteur, Strasbourg, 219 pp.

Reig, O.A., 1961. Acerca de la posición sistematica de la familia Rauisuchidae y del género Saurosuchus (Reptilia-Thecodontia). Publicaciones del Museo Municipal de Ciencias Naturales de Mar del Plata 1 (3), 73-113. 
Reig, O.A., 1963. La presencia de Dinosaurios Saurisquios en los Estratos de Ischigualasto (Mesotriásico superior) de las provincias de San Juan, y La Rioja (República Argentina). Ameghiniana 3, 3-20.

Remane, J., Cita, M.B., Decourt, J., Bouysse, P., Repetto, F.L., FaureMuret, A., 2000. International stratigraphic chart. In: Briggs, D.E.G., Crowther, P.R. (Eds.), Palaeobiology II. Blackwell Science.

Rogers, R.R., Swisher III., C.C., Sereno, P.C., Monetta, A.M., Forster, C.A., Martínez, R.N., 1993. The ischigualasto tetrapod assemblage, late Triassic, Argentina, and ${ }^{40} \mathrm{Ar} /{ }^{39} \mathrm{Ar}$ dating of dinosaurs origins. Science 260, 794-797.

Romer, A.S., 1960. Vertebrate-bearing continental Triassic strata in Mendoza region, Argentina. Bulletin of the Geological Society of America 71, 1279-1293.

Romer, A.S., 1962. La evolucion explosiva de los rhynchosaurios del Triassico. Revista del Museo Argentino de Ciencias Naturales 8, 1-14.

Romer, A.S., 1971. The Chañares (Argentina) Triassic reptile fauna. VIII. A fragmentary skull of a large thecodont, Luperosuchus fractus. Breviora 378, 1-10.

Ross, C.A., Baud, A., Manning, M., 1994. Project Pangea time scale. In: Klein, G.D. (Ed.), Pangea: Paleoclimate, Tectonics, and Sedimentation during Accretion, Zenith, and Breakup of a Supercontinent Geological Society of America, Special Papers.

Roy-Chowdhury, T.K., 1965. A new metoposaurid amphibian from the upper Triassic Maleri Formation of Central India. Philosophical Transaction of the Royal Society of London, Series B 250, 1-52.

Schoch, R.R., Milner, A.R., 2000. Stereospondyli. Handbuch der Paläoherpetologie, teil 3B. Dr Friedrich Pfeil, München, 170 pp.

Schultz, C.L., 1995. Subdivisão do Triássico do RS com base em macrofósseis: problemas e perspectivas. Comunicações do Museu de Ciências e Tecnologia, UBEA/PUCRS, Série Ciências da Terra 1 , $25-32$.

Schultz, C.L., 2004. Biostratigraphy of the non-marine Triassic: is a global correlation based on tetrapods possible?. In: Koutsoukos, E.A.M. (Ed.), Applied Stratigraphy. Kluwer, pp. 123-145.

Schultz, C.L., Scherer, C.M.S., Barberena, M.C., 2001. Biostratigraphy of southern Brazilian Middle-Upper Triassic. Revista Brasileira de Geociências 30, 491-494.

Scotese, C.R., 1994. Late Triassic paleogeographic map. In: Klein, G.D. (Ed.), Pangea: Paleoclimate, Tectonics, and Sedimentation during Accretion, Zenith, and Breakup of a Supercontinent Geological Society of America, Special Papers, p. 228.

Sengupta, D.P., 1995. Chigutisaurid temnospondyls from the Late Triassic of India and a review of the family Chigutisauridae. Palaeontology 38 , 313-339.

Sengupta, D.P., 2002. Indian metoposaurid Amphibians revised. Palaeontological Research 6, 41-65.

Sengupta, D.P., 2003. Triassic temnospondyls of the Pranhita-Godavari basin, India. Journal of Asian Earth Sciences 21, 633-642.

Sereno, P.C., Novas, F.E., 1992. The complete skull and skeleton of an early dinosaur. Science 258, 1137-1140.

Sereno, P.C., Forster, C.A., Rogers, R.R., Monetta, A.M., 1993. Primitive dinosaur skeleton from Argentina and the early evolution of the Dinosauria. Nature 361, 64-66.

Shubin, N.H., Sues, H.-D., 1991. Biogeography of the early Mesozoic continental tetrapods, patterns and implications. Paleobiology 17, 214-230.

Sill, W.D., 1967. Proterochampsa barrionuevoi and the early evolution of the Crocodilia. Bulletin of the Museum of Comparative Zoology 135, 415-446.

Sill, W.D., 1970. Scaphonyx sanjuanensis, nuevo rinchosaurio (Reptilia) de la Formación Ischigualasto, Triásico de San Juan, Argentina. Ameghiniana 7, 341-354.
Sill, W.D., 1974. The anatomy of Saurosuchus galilei and the relationships of the rauisuchid thecodonts. Bulletin of the Museum of Comparative Zoology 146, 317-362.

Spalletti, L.A., Artabe, A.E., Morel, E.M., Brea, M., 1999. Biozonación paleoflorística y cronoestratigrafía del Triásico Argentino. Ameghiniana $36,419-451$.

Steyer, J.S., 2000. Are European Paleozoic amphibians good stratigraphical markers? Bulletin de la Société Géologique de France 171, 127-135.

Stipanicic, P.N., 2002. Quadro geocronógico y de corelacion de las princiales formaciones triássicas argentinas. In: Stipanicic, P.N., Marsicano, C.A. (Eds.), Léxico Estratigráfico de la Argentina, vol. 8. Triásico, Buenos Aires, pp. 340-343.

Stipanicic, P.N., Bossi, G.E., 2002. Ischigualasto (Formación). In: Stipanicic, P.N., Marsicano, C.A. (Eds.), Léxico Estratigráfico de la Argentina, vol. 8. Triásico, Buenos Aires, pp. 149-150.

Stockley, G.M., 1947. New coal discoveries in Tanganyika. Mineralogical Magazine 76, 329-338.

Sulej, T., 2002. Species discrimination of the Late Triassic temnospondyl amphibian Metoposaurus diagnosticus. Acta Palaeontologica Polonica 47, 535-546.

Vega-Dias, C., Schultz, C.L., 2004. Postcranial material of Jachaleria candelariensis Araújo and Gonzaga 1980 (Therapsida, Dicynodontia), Upper Triassic of Rio Grande do Sul, Brazil. Paleobios 24, 7-31.

Vega-Dias, C., Maisch, M.W., Schultz, C.L., 2004. A new phylogenetic analysis of Triassic dicynodonts (Therapsida) and the systematic position of Jachaleria candelariensis from the Upper Triassic of Brazil: Neues Jahrbuch für Geologie und Paläontologie. Abhandlungen 231, 145-166.

Walker, A.D., 1961. Triassic reptiles from the Elgin area: Stagonolepis, Dasygnathus and their allies. Philosophical Transactions of the Royal Society of London, Series B 244, 103-204.

Warren, A.A., Damiani, R.J., 1999. Stereospondyl amphibians from the Elliot Formation of South Africa. Palaeontologia Africana 35, 45-54.

Warren, A.A., Marsicano, C.A., 2000. A phylogeny of the Brachyopoidea (Temnospondyli Stereospondyli). Journal of Vertebrate Paleontology 20, 462-483.

Whatley, R.L., Flynn, J.J., Parrish, J.M., Simpson, W., Wyss, A.R., 1999. Isalorhynchus revisited: Two rhynchosaur skeletons from southwestern Madagascar. Journal of Vertebrate Paleontology 19 (Suppl. to vol. 3), $84 \mathrm{~A}$.

Witmer, L.M., 1997. The evolution of the antorbital cavity of archosaurs: A study in soft-tissue reconstruction in the fossil record with an analysis of the function of pneumaticity. Society of Vertebrate Paleontology, Memoir 3, 1-73.

Woody, D., Parker, W., 2003. A new skeleton of the aetosaur Stagonolepis wellesi (Archosauria: Crurotarsi) from Petrified Forest National Park, Lower Chinle Formation (Late Triassic) of Arizona. Journal of Vertebrate Paleontology 23 (supl. to vol. 3), 112A.

Wroblewski, A.F.-J., 2003. Application of cladistic analysis towards resolving biostratigraphic uncertainty: An example from the Upper Triassic. 55th Annual Meeting of the Rocky Mountain Section. Durango, CO.

Yates, A.M., Kitching, J.W., 2003. The earliest known sauropod dinosaur and the first steps towards sauropod locomotion. Proceedings of the Royal Society of London, Biological Sciences 270 (1525), 1753-1758.

Zanno, L.E., Heckert, A.B., Lucas, S.G., Krzyzanowski, S.E., 2002. Diminutive metoposaurid skulls from the Upper Triassic Blue Hills (Adamanian: Latest Carnian) of Arizona: Ontogenetic and phylogenetic implications. Journal of Vertebrate Paleontology 22 (supl. to vol. 3), $121 \mathrm{~A}$. 